\title{
Ethics and Professionalism in Non-Adversarial Lawyering
}

Carrie Menkel-Meadow

Georgetown University Law Center, meadow@law.georgetown.edu

This paper can be downloaded free of charge from:

https://scholarship.law.georgetown.edu/facpub/1758

\section{Fla. St.U. L. Rev. 153}

This open-access article is brought to you by the Georgetown Law Library. Posted with permission of the author. Follow this and additional works at: https://scholarship.law.georgetown.edu/facpub

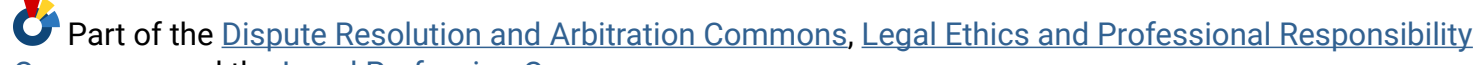




\title{
ETHICS AND PROFESSIONALISM IN NON- ADVERSARIAL LAWYERING
}

\author{
CARRIE MENKEL-MEADOW*
}

I. INTRODUCTION

II. THE TEN COMmandments of APpropriate DispUte Resolution: AN ASPIRATIONAL CODE

III. Proposed Model Rule of Professional CONDUCT: THe LAWYer as THIRD PARTY NEUTRAL.

\section{INTRODUCTION}

Traditional notions and rules of professionalism in the legal profession have been premised on particular conceptions of the lawyer's role, usually as an advocate, ${ }^{1}$ occasionally as a counselor, advisor, transaction planner, government official, decision maker and in the recent parlance of one of this symposium's participants-a "statesman [sic]." As we examine what professionalism means and what rules should be used to regulate its activity, it is important to ask some foundational questions: For what ends should our profession be used? What does law offer society? How should lawyers exercise their particular skills and competencies?

While it is true that the lawyer is an advocate and uses her skills to persuade others on behalf of her client-her principal-lawyers are also "officers of the court" with loyalties and allegiances to the public good, and sometimes, its agencies. As others have elaborated, lawyers have duties to practice justice. ${ }^{3}$ And, we have heard much in this symposium, as well as in modern professional discourse, about the tensions between the paradigms of "law as a profession" and "law as a business." 4

- Professor of Law, Georgetown University Law Center and Chair, CPR-Institute for Dispute Resolution-Georgetown Commission on Ethics and Standards in ADR. Thanks to Professor Jeff Stempel for the invitation to return to Florida State University College of Law and to the other symposium participants for stimulating thoughts and comments.

1. See Carrie Menkel-Meadow, Ethics in Alternative Dispute Resolution: New Is. sues, No Answers from the Adversary Conception of Lawyers' Responsibilities, $38 \mathrm{~S}$. TEX. L. REV. 407 (1997) [hereinafter Menkel-Meadow, Ethics in Alternative Dispute Resolution]; Carrie Menkel-Meadow, The Silences of the Restatement of the Law Governing Lawyers: Lawyering as Only Adversary Practice, 10 GEO. J. LEGAL ETHICs 631 (1997) [hereinafter Menkel Meadow, Silences of the Restatement].

2. ANTHONY KRONMAN, THE LOST LAWYER (1994).

3. See David Luban, LaWyers and JUSTICE: AN ETHICAL STUDY xvii, xxii (1988); see also William Simon, THE PRACTICE OF JUSTICE: A THEORY OF LAWYERS' ETHICS 12 (1998) (suggesting that ethical rules are one way to "alleviate the moral anxiety" of lawyers).

4. See Russell G. Pearce, Law Day 2050: Post-Professionalism, Moral Leadership, and the Law-As-Business Paradigm, 27 FLA. ST. U. L. ReV. 9 (1999) [hereinafter Pearce, Law Day 2059. The profession-business tension has been with us since at least the early 18th century, though some would claim the rhetoric about different masters as justice or manna has been with us since the beginning of American legal history. See LAWRENCE FRIEDMAN, A HISTORY OF AMERICAN LAW (1985). 
I want to suggest, as I have before, ${ }^{5}$ that lawyers serve other functions as well and that our rules of professionalism do not adequately reflect some of these other functions-the lawyer as problem solver, ${ }^{6}$ peacemaker? and third party neutral, as some examples. Too much of the debate about professionalism, it seems to me, has been clustered around a series of false dichotomies or polarizations-business ver. sus profession, client defense (zeal) versus truth, adversarialism versus compromise, criminal versus civil, public versus private, client service and autonomy vs. justice, individualism vs. system, rules of law and discretion-as if our actual practices do not often combine aspects of these claimed opposites simultaneously.

Law is a profession and clearly is concerned with, and suffering from, market competition and other economic influences. Lawyers simultaneously serve their clients and have duties and obligations to the profession itself and to the larger society and its public agencies. Lawyers often serve clients in adversarial settings like litigation or contested transactional negotiations, but they also serve clients in non-adversarial roles where there is no adversary at all (will drafting, business advice) or even serve people as lawyers without having them in formal client relationships (serving on boards of directors, acting as mediators, facilitators or consensus builders). ${ }^{8}$ There are no easy stopping points along many of these continua.

To the extent that lawyers and legal academics have an obligation to diagnose, solve and reform legal issues, it seems imperative that we take account of the complexity of lawyer roles and not use simple "paradigms" to obscure more functional complexity. As a former practicing lawyer and a long-time ethics teacher, I have questioned the desirability of transsubstantivity in both ethical and procedural rules, ${ }^{9}$ when functional specificity may be required for more clarity of

5. See Carrie Menkel-Meadow, Taking Problem Solving Pedagogy Seriously, $49 \mathrm{~J}$. Legal Educ. 14 (1999); Carrie Menkel-Meadow, To Solve Problems, Not Make Them: Integrating $A D R$ in the Law School Curriculum, 46 SMU L. REV. 1995 (1993); Carrie Menkel-Meadow, Toward Another View of Legal Negotiation: The Structure of Problem Solv. ing, 31 UCLA L. REv. 754 (1984) [hereinafter Menkel-Meadow, Toward Another View].

6. See Carrie Menkel-Meadow, The Art and Science of Problem-Solving Negotiation, TrIal, June, 1999 at 48; Menkel-Meadow, Toward Another View, supra note 5.

7. It was Abraham Lincoln, that consummate advocate, who exhorted his profession to: "discourage litigation. Persuade your neighbors to compromise whenever you can. Point out to them how the nominal winner is often a real loser-in fees, expenses, and waste of time. As a peacemaker, the lawyer has a superior opportunity of being a good man. There will still be business enough [sic]." Abraham Lincoln, Fragment: Notes for a Law Lecture, in THE COLLECTIVE WORKS OF ABRAHAM LINCOLN: SUPPLEMENT 1832-1865, 18-19 Roy Basler ed., 1974). In the original speech he said "never encourage" rather than "discourage" litigation.

8. See Consensus BuIlding HaNdBook (Larry Susskind ed., 1999).

9. See Carrie Menkel-Meadow, Ethics and the Settlements of Mass Torts: When the Rules Meet the Road, 80 CORNELl L. REV. 1159 (1995); see also Eleanor Myers, "Simple Truths" About Moral Education, 45 AM. U. L. REV. 823 (1996). 
role, guidance necessary for professional actors and clearer statements of purpose for the consumer of such services. Though professions often desire general rules of ethics to unify and mark the boundaries of what a profession is, increasingly, general ethics and professionalism may be so general and abstract as to be of little use both to those who need to act as professionals, with guidance from appropriate rules and standards, and to those who need to judge the actions of professionals-both consumers and regulators of various kinds. ${ }^{10}$ To the extent that we too narrowly define the frame or prism through which we define lawyers' roles, we may be providing inadequate ethical guidance for lawyers and too narrowly crafting what services lawyers can provide. ${ }^{11}$ In short, this is an argument for functional ethics, recognizing a broader set of functions for the lawyer in some non-adversarial settings than current conceptions of ethics or professionalism seem to want to recognize.

For some, lawyers are the servants of a system that utilizes "the rule of law" to restrain what might be the despotic or corrupt rule of particular individuals. Lawyers are thus agents of a particular system that has its own justification. David Luban, for example, has examined whether the lawyer's activities as an advocate in an adversary system can be justified by the defense of the larger system in which the lawyer is located-the adversary system..$^{12}$ Others have framed the lawyer's role in different ways: the "transaction cost engineer," 13 the "process architect,"14 the purveyor of justice or officer of the court ${ }^{15}$ with "referential" ethical responsibility placed in the "reputational" market (for transactional work) or a jurisprudential or

10. In general, regulation of professionals has itself become more complex, including, for the legal profession, disciplinary bodies in the states, court decisions through disqualification, sanction and withdrawal motions, federal agencies with their own rules of admission and practice (IRS and SEC, as examples), and increasingly, the transdisciplinary actions of professional associations that either certify or hope to regulate best practices in some professional fields, such as mediation or paralegals. See, e.g., AAAABA/SPIDR, MODEL STANDARDS OF CONDUCT FOR MEdiatorS (1995); L. Ray Patterson, LAWYER's LAW: PROCEDURAL, MALPRACTICE AND DISCIPLINARY ISSUES (4th ed. 1999).

11. In this essay I am principally concerned with lawyers' roles in dispute resolution and what I call "transactional ADR," but there are many other related issues of other functions to be performed by lawyers currently being addressed by the ABA Commission on Multi-Disciplinary Practice. See Report (visited June 9, 1999) <http://www.abanet.org/cpr/mdpreport.html> (suggesting Model Rule revisions to permit, with certain rules and regulations, multi-disciplinary practice of lawyers with nonlawyers and allowing fee-splitting with other non-legal professionals; see also Ritchenya Shepard, Lawyers, Accountants and Beyond, NAT'L L.J., June 21, 1999, at A.1.

12. See David Luban, The Adversary System Excuse, in THE GoOD LAWYER: LAWYERS ROLES AND LAWYERS' ETHICS (David Luban ed., 1984).

13. Ronald Gilson, Value Creation by Business Lawyers: Legal Skills and Asset Pricing, 94 YALE L. J. 239, 244 (1984).

14. ROBERT MNOOKIN, Beyond Winning: How LaWyers Help Clients CREate VALUE IN NEGOTIATION (forthcoming).

15. See SimON, supra note 3, at 9. 
legalistic definition of "systemic" justice (for litigation). To the extent that lawyers serve different functions, with their particular expertise located in different process functions, it may be that ethics will have to be specifically related to function and form of the activity within specific and, perhaps, different institutional settings. ${ }^{16}$

In a recent book examining adversarial ethics (and finding them wanting), Arthur Isak Applbaum acknowledges the ethics of professional function (and suggests these can go too far) by recounting the ability of Charles-Henri Sanson in maintaining his position as Executioner of Paris through changes in regime from Louis XVI through all the stages of the French Revolution, because of his extreme professional and functional ethics ${ }^{17}$-he was simply a professional executioner and the underlying political regime for whom he did his work did not matter. ${ }^{18}$ What did matter was how and with what professional standards of quality he performed his work. I want to suggest the danger of Sanson's success-the assumption in our own code of legal ethics, that a lawyer is a lawyer and that all lawyers can be regulated, by the same rules, regardless of how or for whom they perform their services.

Though the analogy is not totally apt, Sanson's ethics as an Executioner transcending political regime is a bit like the expectation of our current ethical codes - that a lawyer can be governed by a unitary code as long as he is called a "lawyer," regardless of whether his "political regime" is the adversarial world of advocacy or not. Some have suggested that we can avoid these problems by claiming that a lawyer who performs non-adversarial roles, like arbitrator-judge or mediator, is simply not acting as a lawyer. ${ }^{19}$ However, I have argued

16. I have often thought of Lon Fuller as the "jurisprude" of ADR. His series of articles discusses the particular structures and competencies of adjudication, arbitration and mediation as different legal processes. In the debates about ADR, the 1950s Legal Process school's insights about "institutional competence" continue, suggesting that different forms and institutions within the legal system may also require different ethical systems. See Menkel-Meadow, Ethics in Alternative Dispute Resolution, supra note 1, at 415-21, 417 n.41; see also David Luban, Rediscovering Fuller's Legal Ethics, 11 GEo. J. LEGAL ETHICS 801,807 (1998).

17. See ARTHUR ISAK APPLBAUM, ETHICS FOR ADVERSARIES: THE MORALITY OF ROLES IN PUBLIC AND PROFESSIONAL LIFE (1999).

18. This extreme form of "functional" professional ethics is also examined in Kazuo Ishiguro's novel, REMAINS OF The DaY (1989). See Rob Atkinson, How the Butler was Made to Do It: The Perverted Professionalism of the Remains of the Day, 105 YALE L.J. 177 (1995); see also David Luban, Stevens's Professionalism and Ours, 38 WM. \& MARY L. REV. 297 (1996).

19. See Symposium, Is Mediation the Practice of Law?, NIDR FORUM, June 1997; see also Geoffrey C. Hazard, Jr. When ADR Is Ancillary to a Legal Practice, Law Firms Must Confront Conflicts Issues, 12 ALTERNATIVES TO HIGH COST LITIG. 147 (1994); Bruce Meyerson, Lawyers Who Mediate Are Not Practicing Law, 14 ALTERnATives to High Cost LiTIG. 74 (1996); Geetha Ravindra, When Mediation Becomes the Unauthorized Practice of Law, 15 Alternatives to High Cost Litig. 94 (1997); N.J. Panel Finds ADR Is Part of Law Practice, 12 Alternatives to High Cost Litig. 87 (1994). 
otherwise, suggesting that such roles do implicate the use of law and its "practice" in the reliance third parties may place on legal interpretations, even if they are not clients. ${ }^{20}$

Though the adversary system is both defended and found wanting for its claim that it is the best method for learning the truth, ${ }^{21}$ or, alternatively, for protecting individual rights, ${ }^{22}$ or, because when compared with various alternatives, it is considered the fairest by participants, ${ }^{23}$ other forms of legal and non-legal problem solving are growing in importance because they emphasize other values. A recent reform effort in the United Kingdom, for example, has borrowed aspects of the continental inquisitorial system by using single, courtappointed experts to reduce adversarialism among competing and "bought" experts and is suggesting court-structured fee schedules (borrowed from Germany) to add predictability and, presumably, access to legal services. ${ }^{24}$

As Bill Simon recently demonstrated so eloquently, even the ethics of the adversary system are self-contradictory, or, in the old words of critical legal studies, "indeterminate" because the guiding ethical concepts of the "zealous advocate" limited by the "bounds of the law" are often either in tension with each other or have no clear lines of demarcation. ${ }^{25}$ Furthermore, as Simon and others have argued, in our current legal culture, the "zeal" of the advocate for his client has trumped whatever "supplementary" values are intended to be expressed in the duties of the "officer of the court" who has responsibilities to the larger system of justice. ${ }^{26}$

Even the notion of "officer of the court" as an ethical counterpoint to consider the justice or fairness of one's acts as a zealous advocate falls far short of today's law practice realities. If taken literally, the lawyer's duty to be an officer "of the court," intending to connote

20. See Carrie Menkel-Meadow, Is Mediation the Practice of Law?, 14 ALTERnATIVES To HIGH COST LITIG. 57 (1996); see also To the Editors: Is Mediation the Practice of Law Redux, NIDR NEWS, Nov. 1997-Jan. 1998, at 1 (1998).

21. See LUBAN, supra note 3 , at 68-74; see also Marvin E. Frankel, Partisan JUSTICE (1980); Carrie Menkel-Meadow, The Trouble with the Adversary System in a Postmodern, Multicultural World, 38 WM. \& MARY L. REv. 5, 5.6 (1996) (providing a critique of the adversary system and its binary nature) [hereinafter Menkel-Meadow, Trouble].

22. See Monroe Freedman, UndersTanding LAWYER's ETHICS 16 (1990); Monroe Freedman, The Trouble with Postmodern Zeal, 38 WM. \& MARY L. REV. 63 (1996).

23. See John THibaut \& LaURENS Walker, Procedural Justice: A PSYchological ANALYSIS (1975); see also John Thibaut et al., Adversary Presentation and Bias in Decisionmaking, 86 HARV. L. REV. 386, 386-88 (1972) (discussing research that appears to support the validity of an adversarial model).

24. See Lord Woolf, Access to Justice: Final Report, REPORT TO THE LORD Chancellor ON THE CIVIL JUSTICE SYSTEM IN ENGLAND AND WALES (July 1996).

25. See SIMON, supra note 3, at 7-8.

26. See id. at 9-10 (arguing for a discretionary approach to lawyering that considers a wide range of circumstances "to promote justice"). 
some loyalty to the system, beyond the client's demands, would seem to apply to those matters in litigation, or at least those in anticipation of litigation. ${ }^{27}$ How should the lawyer's duty to the system be expressed for non-court lawyer activities-the lawyer as counselor, will drafter, negotiator, or, in the major role which is my theme here, as third party neutral?28 The lawyer is not always an officer of the court when performing legal tasks; thus, the reference point for professionalism and ethics must be something beyond the lawyer's duty to a tribunal or specific office, whether located in a specific institution or within the more generalized institution of litigation.

I have written at length elsewhere that the adversarial system, though serving some functions, is potentially deficient in meeting some human goals. ${ }^{29}$ To the extent that the structure of adversarialism privileges argument, debate, bipolar or binary solutions and often channels disputes or issues into simplistic two-sided treatment, this stylized form prevents recognition of the more common ways in which legal problems occur in our modern world. Even conventional lawsuits these days are often disputes or issues between and among multiple parties (i.e. environmental clean-ups, mass torts, securities, reform of governmental entities, consumer actions), often with multiple issues at stake-what Lon Fuller called "multi-plex" disputes, which are not susceptible to litigious on/off, yes/no solutions. ${ }^{30}$ These kinds of cases may require complex solutions, with future-oriented rules, transactions or duties and cannot adequately be served by the "limited remedial imaginations" of courts. ${ }^{31}$

Some lawyers represent entities, either from within or without, and must manage internal organizational or "constituency" prob-

27. For those cases that are actually filed, we know that over $90 \%$ are resolved without trial in court. This does not mean, as many continue to suggest, that $90 \%$ of cases settle. Many, in fact, are resolved by judicial decision or other means (motions for summary judgment, etc.). See Herbert Kritzer, Adjudication to Settlement: Shading in the Gray, 70 JUDICATURE 161, 161 (1986). Of course, "officer of the court" also implicates the complex ethical dispute about when lawyers as advisors (particularly in regulatory advice giving) are acting on the basis of "anticipation" of litigation, as became an issue in the Lincoln Savings and Loan disciplinary charges. See Stephen Gillers \& Roy D. Simon, The Kaye Scholer File, in REgULATION OF LAWYERS: STATUTES AND STANDARDS 729, 731 (1992).

28. I have continually raised the issue of whether a lawyer appearing in a private mediation, arbitration, or in a court-annexed program is appearing before a "tribunal" as defined in the Model Rules of Professional Conduct, or, now, in the Restatement of the Law Governing Lawyers. See Menkel-Meadow, Ethics in Alternative Dispute Resolution, supra note 1; see also Menkel-Meadow, Silences of the Restatement, supra note 1.

29. See Menkel-Meadow, Trouble, supra note 21.

30. Lon Fuller, Mediation-Its Forms and Functions, 44 S. CAL. L. REV. 305, 306-07 (1971).

31. Menkel-Meadow, Toward Another View, supra note 5 (suggesting that courts have limited remedial imaginations, not because judges are not imaginative, but because com. mon law and statutes and the very structure of the legal system limit what courts are allowed to do and what solutions they are allowed to see). 
$\mathrm{lems}^{32}$ as a matter of advice and counsel, whether or not there are particular legal disputes with the outside world. Modern in-house counsel or ombudsman-like lawyers may deal as much with internal organizational issues and management than with outside disputes, calling for very different skills and approaches to legal problem solving..$^{33}$ Other lawyers are engaged to help individuals or entities form organizations or partnerships, draft wills or contracts, and may or may not have "issues" or "adversaries" in the way the adversarial model of lawyering understands them.

If finding the truth, learning what happened in the past, and pro. tecting individual rights are not the only values a legal system should express, then perhaps we need to recast the goals that lawyers and the legal system might seek to achieve. Furthermore, we might need to rethink the rules that are intended to guide and regulate lawyers seeking to achieve those different goals. What if, for example, we saw lawyers and the legal system seeking to solve not only client problems, but also seeking to work on community-based or even larger social problems? What if needs, as well as rights, were part of the lawyer's vocabulary? Notions of loyalty would be different. So, would there need to be different rules regarding confidentiality? If, as in other cultures, we began to value harmony ${ }^{34}$ and peace, as much as contention and rights, lawyers seeking to reduce, rather than increase, conflict might have to operate in different ways.

If, as I suggested some years ago, and which is now becoming a more popular notion with many, including the Attorney General, ${ }^{35}$ we considered the lawyer as problem-solver, then lawyers would engage in forward-thinking, planning and preventative strategies, as well as retrospective defenses and claims. What should the defense lawyer's responsibilities be to the criminal defendant who has been successfully defended-acquitted-but who might in fact be guilty? What should the lawyer's responsibility be to prevent future crimes, including not just the commonly mentioned individual crimes of burglary, etc., but corporate crimes of pollution, unfair trade practices, inhumane employment policies? What responsibility should a prosecutor feel for the conviction he achieves when he knows the defendant is

32. See, e.g., GEOFFrey C. HAZARD, ETHICS IN THE PRACTICE OF LAW (1978) (discussing complex duties of lawyers to organizations); DAVID MURRAY, ETHICS IN ORganizations: Values, CODES, Vision, Strategies, ACTION (1997).

33. See Ellen Waxman \& Howard Gadlin, A Breed Apart: An Ombudsman Serves as a Buffer Between and Among Individuals and Large Institutions, DISP. RESOL. MAG., Summer 1998, at 21.

34. For a trenchant critique of "false" harmony values in our mediation culture, see Laura Nader, Controlling Processes in the Practice of Law: Hierarchy and Pacification in the Movement to Re-Form Dispute Ideology, 9 OHIO ST. J. ON DISP. RESOL. 1 (1993).

35. See Janet Reno, Lawyers as Problem-Solvers: Keynote Address to the AALS, $49 \mathrm{~J}$. LEGAL EDUC. 5 (1999). 
headed for a prison system that will educate him in new ways of committing crimes? ${ }^{36}$ What responsibility should a lawyer feel for the community when he has won a zoning variance or tax relief for a developer? These examples suggest that there might be commitments beyond the client when the lawyer's own actions or work allow the client to do things that affect others. Our current rules recognize that lawyers may be ethically liable when their actions have been implicated in their clients' fraudulent acts. ${ }^{37}$ To the extent that lawyers' actions cause harm to others, what responsibilities should the lawyer have for preventing or resolving such problems before they occur?

What if every law student and lawyer asked at the beginning of every traditional case: What caused this dilemma? This problem? Is the dispute just the tip of an iceberg where the whole iceberg needs melting? What is the larger context in which this problem is situated? What would need to be done to fix the problem or to address the concerns of the parties and those affected by whatever decisions might be made? This more pro-active approach to legal problem solving would involve the lawyer in different functions and tasks than those now often employed within traditional legal paradigms and skills. Problem solving and mediation literature commonly speak of lawyers who define problems narrowly (dispute resolvers or litigators) and those who seek broader issue definition for broader problem resolution. ${ }^{38}$ Should one's ethical duties be commensurate with the size of the problem or responsibilities that one takes on $?^{39}$

Lawyers, for example, might be instrumental in convening meetings of interested group $\mathrm{s}^{40}$ seeking to resolve issues before, during, or after lawsuits, using very different techniques than traditional adversarial approaches. In a variety of complex disputes, including block grant allocation, environmental clean up and siting, municipal funding and governance, racial tensions, police accountability and reorganizations of human services agencies, new kinds of processes, variously called "consensus building," ${ }^{41}$ strategic planning, joint prob-

36. See Robert Suro, Law \& Order: Counting Toward 100,000 More Police, WASH. POST, June 1, 1999, at A-13 (excerpting Janet Reno's graduation speech to Tulane Law School).

37. See, e.g., MODEL RULEs Rules 1.2, 1.6, 3.3, 4.1 (1995) [hereinafter MODEL RULES].

38. See, e.g., Leonard Riskin, Understanding Mediators' Orientations, Strategies and Techniques, 1 HARV. NEGOTIATION L. REV. 7, 13 (1996) (providing a grid for categorizing types of mediation).

39. For example, Judith Maute has argued that mediators should bear greater ethical responsibility when they "preside" over cases where parties are not represented. See Judith Maute, Public Values and Private Justice: A Case for Mediator Accountability, 4 GEo. J. LEGAL ETHICS 503, 508 (1991).

40. See Philip Harter, Negotiating Regulations: $A$ Cure for Malaise, 71 Geo. L.J. 1 (1982) (discussing the role lawyers might play in negotiations concerning administrative procedure); see also Jody Freeman, Collaborative Governance in the Administrative State, 45 UCLA L. REV. I (1997).

41. See, e.g., CONSENSUS BUILDING HANDBOOK, supra note 8. 
lem solving, community education, ${ }^{42}$ public conversations ${ }^{43}$ and meeting facilitation, ${ }^{44}$ have been used by lawyers and others to facilitate new forms of problem solving with multiple parties and interested stakeholders. These new processes may very well need new kinds of rules or expectations about their own ethics and professionalism, where service is to groups of people who are not "clients" in the strictly legal or adversarial sense. Duties to explain the legal significance of these processes clearly, to treat confidentiality differently, to be accountable to various affected parties, ${ }^{45}$ and to be neutral and unbiased may take on different meanings in these new contexts.

Even within more traditional lawyer roles, the current rules must respond to the many ways in which lawyers are intersecting with less conventional forms of legal process. Some states have already recognized the new ethical obligation of the lawyer to advise and counsel the client about other means for resolving problems beyond the obvious choice of litigation. Colorado and Georgia, for example, have required lawyers to discuss alternative processes with clients, ${ }^{46}$ and now, many courts, especially those with mandatory ADR programs, may require such counseling as a matter of procedural, rather than ethical mandates. If the lawyer's responsibilities are to help clients, and possibly others, achieve their legitimate ends, then advice about the most effective and efficient way to achieve those goals would seem to be an obvious and integral part of the lawyer's obligations.

To the extent that lawyers may interact more directly, either with represented, or even with unrepresented parties, ${ }^{47}$ what obligations ought lawyers to have in dealing directly with parties who are not their own clients? ${ }^{48}$

42. See Ingrid Eagly, Community Education: Creating a New Vision of Legal Services Practice, 4 Clinical L. REv. 433 (1998).

43. See, e.g., Symposium, Innovations in Process: New Applications for ADR, DISP. RESOL. MAG., Winter 1997, at 1.

44. See ROger Schwarz, The SkIlled facilitator: Practical Wisdom fOR DEVELOPING EFFECTIVE GROUPS (1994).

45. See, e.g., Larry Susskind, Environmental Mediation and the Accountability Problem, 6 VT. L. REV. 1 (1981). But see Joseph Stulberg, The Theory and Practice of Mediation: A Reply to Professor Susskind, 6 VT. L. Rev. 85 (1981).

46. See, e.g., Colorado Rules of Professional Conduct Rule 2.1 (1992); Ga. R. CIV. P. Rule EC7-5; see also Art Garwin, Show Me the Offer, A.B.A. J., June 1997, at 84; Mich. State Bar Comm. on Prof. and Judicial Ethics, Informal Op. RI-255 \& RI-262; Kansas Bar Assoc. Comm. on Ethics-Advisory Services, Op. 94-01; Pennsylvania Bar Assoc. Ethics, Op. 90-125.

47. See Russell Engler, Out of Sight and Out of Line: The Need for Regulation of Lawyers' Negotiations with Unrepresented Poor Persons, 85 CALIF. L. REV. 79, 81.82 (1997) (arguing that more enforcement and clarification of Model Rule 4.3 and Model Rule DR 7. $104(\mathrm{~A})(2)$ is needed when lawyers act adversarily with those who are unrepresented and cannot protect themselves).

48. A growing body of law is taking on the question of what responsibilities and liabilities lawyers may have to third parties who are not their clients, but who may rely on 
In exploring the lawyer's role as "peacemaker," my principal concern here, I want to focus on the role that lawyers play when they assist parties in resolving disputes outside of court or utilize new forms of appropriate dispute resolution, even in transactional work, or "transactional ADR," as I have come to call it. Our conventional rules of ethics are particularly inapposite when lawyers serve in quasijudicial roles as arbitrators,,$^{49}$ or as mediators, facilitating negotiations among and between parties, but not deciding anything. Third party neutrals, like mediators and consensus-building facilitators, seldom decide cases or "find" facts. Such people are trained to probe for parties' underlying needs and interests and to focus on commonalities as well as differences. Rather than focusing on aggressive persuasiveness, third party neutrals ask parties and their lawyers to use creativity, patience, persistence, flexibility and resilience, without rigid or premature closure on a problem. Some processes are particular to the forms - caucuses and other separate meetings with parties and stakeholders look like ex parte contacts, which would ordinarily be prohibited by traditional rules of legal ethics, but, in these contexts, separate meetings are often contracted for, though perhaps still require some ethical regulation ${ }^{50}$ like requiring disclosure of practices and clarity regarding confidentiality obligations. ${ }^{51}$

Many mediators and facilitators seek to involve all "stakeholders," like insurers or relevant community members, even when they are not formally part of a lawsuit, thus complicating the layers of involvement lawyers may have with different participants. Mediation and other less adversarial problem-solving techniques produce different outcomes. For example, the outcomes may be provisional and dynamic, rather than decided and static and may require continuous monitoring and continuing relations with the parties.

their work or representations. See, e.g., Symposium, The Lawyer's Duties and Liabilities to Third Parties, 37 S. TEX. L. REV. 957 (1996).

49. Many think that the Judicial Code of Conduct can be used as a benchmark for ethical standards and professionalism in situations where lawyers play adjudicative roles. I do not agree, since the judge has a permanent role, which allows him to be at arms length from parties on a regular basis. Arbitrators who may depend on parties choosing and pay. ing them may be closer to lawyers seeking clients in some respects, while resembling judges in others. The American Arbitration Association has promulgated several ethics codes for arbitrators, taking account of the different subject matters in which they operate. See, e.g., ETHICAL RULES FOR COMMERCIAL ARBITRATORS (1977) (now under revision); ETHICAL RULES FOR LABOR AND EMPLOYMENT ARBITRATORS.

50. See Carrie Menkel-Meadow, Ex Parte Talks with Neutrals: ADR Hazards, 12 ALTERNATIVES TO High Cost LiTIG. 109 (1994).

51. Some sophisticated states now statutorily regulate matters like confidentiality in mediation. See Nancy Rogers \& Crajg McEwen, Mediation: LaW, Policy, Practice (2d ed. 1994). The current draft of a proposed Uniform Mediation Act being considered by the National Conference of Commissioners on Uniform State Laws deals with some of these is. sues as substantive regulatory matters. See Richard C. Reuben \& Nancy Rogers, Uniform Mediation Act Goes Public for Comments, DisP. Resol. MAG., Summer 1999, at 18-19. 
Lawyers also perform different functions as "representatives" in these other processes. Several commentators have suggested that because lawyers' roles in these settings are so different, these alternative techniques require new rules and different terminology. ${ }^{52}$ In part, because of the increased use of "warmer"53 dispute resolution techniques, we are beginning to reexamine what the appropriate level of candor should be between lawyers in both private negotiation settings and in certain ADR settings. ${ }^{54}$ If the ethical reference point is "solving the problem", "doing justice" or even "achieving Pareto optimal solutions" rather than winning, zeal, or the "adversary system excuse," then we will have to consider the opposing side more as a "joint venturer" than an adversary. Furthermore, we may be in many settings where there is no adversary at all, or where adversarialism may shift from time to time, in all its postmodern glory, with coalitions concentrating on different issues within a transaction or dispute..$^{85}$ Lawyers would be called on to facilitate, create and synthesize, as well as to analyze, argue and criticize. Learning to "think out of the box" and be creative about solutions would be contradictory to the conventional lawyer's approachsimply looking for the best precedent.

As these new roles for lawyers proliferate, new ethical issues arise for which there are no clear answers. Some suggest it is too early to crystallize these new forms of practice and rigidify them with rules or regulations, or use professional regulation to act as a gatekeeper to a new profession with many possible disciplinary homes. While I

52. See, e.g., Roger Fisher, What about Negotiation as a Specialty?, 69 A.B.A. J. 1221 (1983) (advocating negatiation as specialization, apart from strategical litigation techniques); Robert W. Rack, Jr. Settle or Withdraw: Collaborative Lawyering Provides Incentives to Avoid Costly Litigation, DISP. RESOL. MAG., Summer 1998, at 8 (discussing a new trend toward "collaborative lawyering" in which lawyers and clients enter contractual agreements to "negotiate in good faith until an agreement is found").

53. David Smith, A Warmer Way of Disputing: Mediation and Conciliation, 26 AM. J. COMP. L. 205 (1978).

54. See Philip Schrag \& Lisa Lerman, Testimony Before Ethics Commission 2000, (June 4, 1999). In the last attempt to change the ethics rules, there were proposals to make candor a process requirement of negotiation and "conscionability" a substantive requirement. See MODEL RULES Rules 4.2, 4.3 (Discussion Draft 1983). In this era scholars de. bated whether candor and a standard of preventing "unconscionability" in lawyer-assisted negotiations were enforceable in arenas of totally private behavior. See Murray Schwartz, The Professionalism and Accountability of Lawyers, 66 CAL L. REV. 669, $682-83$ (1978); see also James J. White, Machia velli and the Bar: Ethical Limitations on Lying in Negotiations, 1980 AM. B. FOUND RES. J. 926, 927-28 (arguing that ethical norms may be violated more readily in negotiation setting because of the private nature of the parties' interac. tions). For a more modern view of the self-enforcing market in reputational ethics see Eleanor Holmes Norton, Bargaining and the Ethic of Process, 64 N.Y.U. L. REV. 493, 501 (1989) (arguing that a "functionalist" approach to bargaining produces ethical behavior by making negotiation reputation more public).

55. See Gary Goodpaster, Coalitions and Representative Bargaining, 9 OHIO ST. J. ON DISP. RESOL. 243, 250 (1994) ("Coalition formation occurs when parties negotiate an alliance agreement, formally or informally, expressly or tacitly."). 
am sympathetic to these arguments and have long supported flexibility in developing these creative approaches to problem solving, we simply cannot ignore the numerous professionalism issues surrounding this new area of practice.

First, a lawyer engaging in these kinds of non- or less- adversarial situations ${ }^{56}$ is still disciplinable as a lawyer for the things she does in any setting if the conduct violates the applicable lawyer disciplinary rules. ${ }^{57}$ Besides lawyer ethics codes, there are pesky questions of potential legal malpractice liability. So far, I am not aware of any reported case in which a lawyer has been held liable for mediator malpractice; however, I have heard of unreported settlements. Liability coverage is now being underwritten for mediator malpractice, and there are reported cases of unsuccessful efforts to hold lawyers liable for their actions as third party neutrals. ${ }^{38}$

The proliferation of ethics codes and standards by a variety of third party neutral professional association ${ }^{59}$ makes clear that those who practice these forms of problem solving, professional facilitation, and "neutraling" see a need to professionalize by having standards and exerting some form of quality control over those who perform such services. Though such efforts are often criticized as market control projects, most of these organizations have active ethics committees that hear complaints from consumers and also attempt to develop "best practices" standards.

Furthermore, ADR practitioners are actively seeking ethical guidance when faced with the complex ethical issues confronting third party neutrals, parties themselves and their representatives in these processes. I have canvassed most of these issues at length else-

56. One must remember that many of these alternative processes have their adversarial components. Presentations by representatives in arbitration are as adversary as any activity that lawyers engage in, and even mediation presentations have become increasingly adversarial, opportunistic and gaming over time as experienced lawyer-advocates become party representatives and mediators. See Gail Cox, Arbitration is No Simple Matter, NAT'L L.J., June 28, 1999, at A1; BenNeTT PiCKer, MEdiation Practice Guide; A HANDBOOK FOR RESOLVING BUSINESS DISPUTES (1998) (providing guidance to practitioners in an increasingly more formal area of legal work); CPR INSTITUTE FOR DISPUTE RESOlUTION, MEDIATOR'S DESKBOOK (K. Scanlon ed., 1999) (same).

57. Such rules might include confidentiality rules, contacts with unrepresented parties, fees, advertising, and practicing with nonlawyers or others.

58. See Lange v. Marshall, 622 S.W.2d 237 (Mo. App. 1981) (involving an attempt to sue mediator for malpractice); see also Wagshall v. Foster, 28 F.3d 1249, 1251 (D.C. Cir. 1994) (involving suit against mediator and holding that while acting as court-appointed mediator and performing within the scope of duty, mediators enjoy immunity from dam. ages); Howard v. Drapkin, 222 Cal. App. 3d 843, 848 (1990); Meyers v. Contra Costa County Dep't of Soc. Servs., 812 F.2d 1154, 1155-56 (9th Cir. 1987). See generally Arthur A. Chaykin, Mediator Liability: A New Role for Fiduciary Duties, 53 U. CIN. L. REv. 731 (1984) (discussing several theories of liability and advocating a "fiduciary duties approach" to address mediator misconduct).

59. For example, the American Arbitration Association, the Academy of Family Mediators, and the Society for Professionals in Dispute Resolution are such associations. 
where, ${ }^{60}$ but they include such formal, rule-based issues as conflicts of interests, ${ }^{61}$ fees, ${ }^{62}$ confidentiality and disclosures of harm, ${ }^{63}$ neu. trality and impartiality, competence, aiding unauthorized practice and relevant duties of candor and disclosure, as well as good faith participation in both private (contractual) and public (courtsponsored or ordered) proceedings. ${ }^{64}$ And, if a lawyer has a duty to correct a fraud on the court under Model Rule 3.3, should a mediator have to correct known perjurious or fraudulent testimony in a later proceeding on the same matter if the mediator knows the information is false? ${ }^{65}$

Beyond the more formalistic ethical dilemmas are other practice issues such as what the mediator should do when she knows one side is misrepresenting facts or law to the other side or to the mediator; what authority a mediator or other third party neutral has to order disclosure of information, and how information should be treated when it is not otherwise discoverable (what I have called proprietary "settlement facts"); what is appropriate for the mediator to do when there are resource or other power differentials between the parties; what role should the mediator play in designing, transmitting and formalizing offers, solutions and agreement drafting; what accountability should the mediator feel for whatever agreement or solution she presides over?

60. See, e.g., Menkel-Meadow, Ethics in Alternative Dispute Resolution, supra note 1; Menkel-Meadow, Silences of the Restatment; see also Baruch Bush, The Dilemmas of Mediation Practice: A Study of Ethical Dilemmas and Policy Implications, 1 J. DISP. REsol. 1 (1994), reprinted in DWIGHT GolaNN, MEDIATING LeGal DispuTES 385 (1996); Leonard L. Riskin, Toward New Standards for the Neutral Lawyer in Mediation, 26 ARIz. L. REv. 329, 329-30 (1984) (proposing new standards and ethical obligations for mediators).

61. Examples of conflicts of interest include those that lawyer-mediators have with current, past or potential future representational clients, as well as past, present or potential future mediation clients, and conflicts that lawyer-mediators have with imputation of their conflicts to other members of their firm.

62. $A D R$ practitioners face questions regarding the ethics of contingent fees and feesplitting with nonlawyers.

63. See Tarasoff v. Regents of Univ. of Cal., 551 P.2d 334, 345-49 (1976) (applying duty of psychologists to disclose "confidential" facts about a patient to prevent harm to a third party).

64. See Edward Sherman, Court Mandated Alternative Dispute Resolution: What Forms of Participation Should be Required?, 46 SMU L. REV. 2079, 2089 (1993) (discussing the "five frequently encountered forms of participation that may be required to comply with court-ordered ADR: good faith participation; exchange of position papers and objective information; minimum meaningful participation; participation with settlement authority; and obligation to pay the third-party neutral's fee").

65. Clearly no current rule or legal standard requires such an undertaking, but courts are beginning to subpoena mediators to testify about a variety of matters involving their work. See, e.g., Carmen v. McDonnell Douglas Corp., 114 F.3d 790, 794-95 (8th Cir. 1997) (holding that employee communications to a mediator were not protected from discovery by an ombudsman privilege). But see Reginald Alleyne, Mediator Immunity, CHRON. J. OF NAT'L ACAD. OF ARB., Mar. 1989, 1 (mediator suggesting he will refuse to testify in order to protect confidentiality as duty of mediator). 
Finally, and perhaps most importantly, parties to these new nonadversarial processes need some understanding of what the ground rules are, where they can go to complain about perceived unfair or corrupt processes, and what relation these processes have to more formal legal processes. To the extent that legal ethics rules have been justified by reference to professional function or legal institutions, these newer, less adversarial processes must develop their animating rationales and justifications to gain acceptability and legitimacy. If non-adversarial processes are to offer better ways of solving human and legal problems, then they must be able to demonstrate that they have coherent ethics and standards of quality and professionalism to those who would use these services. While many argue that the market will adequately control and police here, ${ }^{66}$ a new field, coupled with the complications of multiple disciplinary roots, presents enormous information asymmetries to would-be users. To that end, ethicists in these fields are now engaged in the complicated work of developing best practices and both aspirational and positivistic ethical codes.

I want to close with a classic dilemma in legal ethics, one that has been revisited every time we draft new rules of ethics: Should our ethics codes be aspirational, seeking to express best practices and suggested goals for how we can best do our work and often expressed in grandiose, if inspirational, language? Or, do we need to regulate for Holmes' bad(man) professional?67 Must we make rules clear and draft with an eye toward the lawyer who will use the rules in the most technocratic way ${ }^{68}$ to avoid them and seek self-interest wherever possible?

I leave you with two different formulations, which I have worked on over the past few years. First is an aspirational code expressing the ten most important responsibilities that I think lawyers should undertake when acting in these new capacities. Second, appended to this essay is a detailed and complex ethical rule, currently under submission to the ABA's Ethics Commission 2000 on the possible revision of the Model Rules of Professional Conduct and to the many states enacting ethical rules for third party neutrals. ${ }^{69} \mathrm{I}$ welcome comments and reactions to these formulations. What I most wish to express, however, is that although the ethical issues are difficult and the analogies to the lawyer's role as adversary or advocate will not

66. See, e.g., Pearce, Law Day 2050, supra note 4.

67. See Oliver Wendell holmes, JR., The Path of THe LaW (1968).

68. See Heidi Li Feldman, Codes and Virtues: Can Good Lawyers Be Good Ethical De. liberators?, $69 \mathrm{~S}$. CAL. L. REV. 885, 885 (1996) (contrasting "technocratic" rule manipulation of ethics rules with more discretionary and "sentimentally relevant ethical delibera. tion).

69. This proposed Rule applies to lawyers acting as third party neutrals only-not to others who may also engage in these activities. 
take us very far to resolve these problems, I do not want the complexity of the ethical issues to prevent lawyers from engaging in these new roles; they are difficult and unfamiliar to those with conventional legal educations. ${ }^{70}$ These new roles are our future-in our ability to find new ways to solve problems and meet human needs-and these, it seems to me, are appropriate goals for our profession and our human ethics.

\section{The Ten Commandments OF APPROPRIATE DisPute RESOLUTION: AN ASPIRATIONAL CODE ${ }^{71}$}

1. Lawyers should have an obligation to consider and inform the client about the possible methods of resolving a dispute, planning a transaction, or participating in legislative, administrative or other processes that might best address the client's needs. Lawyers should educate themselves and their clients about all available options for handling the client's matter.

2. Lawyers should promptly communicate all proposals to resolve disputes by any process suggested by other parties, clients or decision-makers.

3. Lawyers should consider and promptly communicate all substantive proposals for dispute resolution or transactional agreements to their clients, including both legally based remedies and resolutions and those that address other needs or interests. Lawyers should assist clients to consider non-legal concerns including social, ethical, economic, psychological and moral implications of any possible solutions or proposals.

4. Lawyers should not misrepresent to or conceal from another person, a relevant fact or legal principle (including opposing counsel, parties, judicial officers, third party neutrals or other individuals who might rely on such statements).

5. Lawyers should not intentionally or recklessly deceive another or refuse to answer material and relevant questions in representing clients.

70. Currently, several projects are underway to attempt to introduce more conflict resolution and problem solving in legal education including the CPR Commission on Legal Education and Problem Solving, funded by the Open Society Institute; the MissouriColumbia curriculum integration and dissemination project, funded by FIPSE; and an interdisciplinary seminar on conflict resolution in the law school curriculum at Stanford, funded by the Hewlett Foundation. As with all attempts to change legal education, only outside funding seems to motivate legal educators to look at new subject matter and new pedagogy, but that is a subject for another day!

71. These aspirational standards were developed through my work with the ABA Section on Dispute Resolution, Ethics Sub-Committee; the Committee has not endorsed these or any other formal formulations of ethics rules for the non-adversarial lawyer. The full section of Dispute Resolution endorsed another set of standards, but these standards have never been approved by the ABA's House of Delegates. See ABA/AAA/SPIDR, STANDARDS OF CONDUCT FOR MEDIATORS (1994). 
6. Lawyers as representatives should not agree to a resolution of a problem or participation in a transaction that they have reason to know will cause substantial injustice to the other party. In essence, a lawyer should do no harm.

7. A lawyer serving as a third party neutral should decline to approve or otherwise sanction an agreement achieved by parties which the third party neutral has reason to know would effect an injustice on a party (or third party).

8. Lawyers serving as third party neutrals, such as arbitrators and mediators, should disclose all reasons the parties might consider relevant in determining if the neutrals have any bias, prejudice or basis for not acting fairly and without improper interest in a matter.

9. Lawyers serving as client representatives or as third party neutrals should fully explain to their clients and parties any and all processes and procedures that will be used to facilitate solutions, make claims, or plan transactions so parties can understand and participate in the decision about what procedures to use.

10. Lawyers should treat all parties to a legal matter as they would wish to be treated themselves and should consider the effects of what they accomplish for their clients. In essence, lawyers should respect a lawyers' golden rule. ${ }^{72}$

\section{Proposed MOdel RULE of Professional CONDUCT For THE LAWYER AS THIRD PARTY NEUTRAL ${ }^{73}$}

The Commission on Ethics and Standards in ADR, sponsored by Georgetown University and CPR Institute for Dispute Resolution has

72. See generally Carrie Menkel-Meadow, Lying to Clients for Economic Gain or Paternalistic Judgment: A Proposal for a Golden Rule of Candor, 138 U. PA. L. REV. 761, 764 (discussing the Golden Rule and its application in the lawyering context) (1990); see also Leslie Griffin, Whose Duties and Liabilities to Third Parties?, 37 S. TEX. L. REv. 1191, 1191 (1996) (arguing that lawyers should be treated as all others in the professional liability context for liability to third parties).

73. The Model Rule of Professional Conduct for the Lawyer as Third Party Neutral has been prepared by the CPR-Georgetown Commission on Ethics and Standards in ADR, sponsored by CPR Institute for Dispute Resolution and Georgetown University Law Center, with support from the William and Flora Hewlett Foundation. The rule's reporters include Carrie Menkel-Meadow, Professor of Law, Georgetown University and Chair, CPRGeorgetown Commission on Ethics and Standards in ADR, and Elizabeth Plapinger, Vice President, CPR and Staff Director, CPR-Georgetown Commission on Ethics and Standards in $\mathrm{ADR}$.

The Rule's drafters are members of the CPR-Georgetown Commission on Ethics and Standards in ADR Drafting Committee. The committee is part of the CPR-Georgetown Commission's Working Group on ADR and Law Practice. The Drafting Committee includes the Honorable Jerome Simandle, the Honorable Edmund Spaeth, John Bickerman, Esq., Lawrence Fox, Esq., Duane Krohnke, Esq., Bruce Meyerson, Esq., Professor Nancy Rogers, Elizabeth Plapinger, Esq. and Professor Carrie Menkel-Meadow. Professor Geoffrey Hazard served as a consultant and commentator for the group. 
drafted this proposed Model Rule for adoption into the Model Rules of Professional Conduct. ${ }^{74}$ We offer here a framework or architecture for consideration by the appropriate bodies of the American Bar Association and any state agency or legislature charged with drafting lawyer ethics rules. ${ }^{75}$

The proposed Model Rule addresses the ethical responsibilities of lawyers serving as third party neutrals in a variety of ADR fora (arbitration, mediation, early neutral evaluation, etc.). As an initial jurisdictional matter, the proposed Rule does not address the ethical requirements of nonlawyers performing these duties ${ }^{76}$ or the ethical duties of lawyers acting in ADR proceedings as representatives or advocates. $^{\text {.7 }}$

74. Earlier efforts have produced suggestions for additions to the Model Rules regarding ADR. See, e.g., Judith Maute, Public Values and Private Justice: A Case For Mediator Accountability, 4 GEO. J. LEGAL ETHICS 503 (1991) (suggesting reform in the mediation context); Robert A. Baruch-Bush, The Dilemmas of Mediation Practice: A Study of Ethical Dilemmas and Policy Implications, $1 \mathrm{~J}$. DISP. RESOL. 1, 3 (1994) (reviewing ethical issues facing mediators). The CPR-Georgetown effort attempts to remedy some of the inadequacies of transdisciplinary ethical code drafting as well as the silences of current legal ethics formulations. See, e.g., AAAABAASPIDR MODEL STANDARDS OF CONDUCT FOR MEDIATORS (adopted in 1994 but not ratified to date by the ABA Board of Governors); Carrie MenkelMeadow, The Silences of the Restatement of the Law Governing Lawyers: Lawyering as Only Adversary Practice, 10 GEO. J. LEGAL ETHICs 631 (1997) (discussing the forthcoming Restatement of Laws Governing Lawyers failing attempt at dealing with ethical issues raised by $A D R$ practice).

75. The proposed Rule is in progress and the Drafting Committee welcomes all comments to Professor Carrie Menkel-Meadow at Georgetown University Law Center, 600 New Jersey Ave. N.W., Washington, D.C. 20001 (meadow@law.georgetown.edu) or Elizabeth Plapinger, Vice President, CPR Institute for Dispute Resolution, 366 Madison Avenue, New York, New York 10017 (eplapinger@cpradr.org).

76. The proposed Rule is designed for incorporation into lawyer ethical codes. The question of what other agencies may promulgate transdisciplinary rules-such as the AAA/ABA/SPIDR Model Standards of Conduct for Mediators, or state statutes governing all mediators, for example-is not addressed.

77. This rule attempts to regulate solely the ethical responsibilities of lawyers serving as neutrals and does not deal with other issues such as the potentially different duties of lawyers as representatives or advocates within ADR settings. See Carrie Menkel-Meadow, Ethics in Mediation Representation: A Road Map of Critical Issues, DisP. Resol. MAG., Winter 1997, at 3 (discussing whether a different set of ethical rules for lawyers involved in the mediation context is necessary and desirable). 


\section{RULE 4.5 THE LAWYER AS THIRd PARTY NEUTRaL ${ }^{78}$}

\section{A. Preamble}

As client representatives, public citizens and professionals committed to justice and fair and efficient legal process, lawyers should help clients, and others needing legal assistance, pursue the most effective resolution of legal problems. This obligation should include pursuing methods and outcomes that cause the least harm to all parties, that resolve matters amicably where possible, and that promote harmonious relations. Modern lawyers serve these values of justice, fairness, efficiency and harmony as partisan representatives and as third party neutrals.

This Rule applies to the lawyer who acts as a third party neutral to help represented or unrepresented parties resolve disputes or arrange transactions among each other. When lawyers act in neutral, non-representative capacities, they have different duties and obligations in the areas addressed by this Rule than lawyers acting in a representative capacity. The current Model Rules are silent on lawyer roles as third party neutrals, which are different from the representational functions addressed by the Model Rules of Professional Conduct and judicial functions governed by the Judicial Code of Conduct..$^{79}$

Contemporary law practice involves lawyers in a variety of new roles within the traditional boundaries of counselors, advocates and advisors in the legal system. Now lawyers commonly serve as third party neutrals, either as facilitators to settle disputes or plan transactions, as in mediation, or as third party decision-makers, as in arbitration. Such proceedings, including mediation, arbitration and other hybrid forms of settlement or decision making, occur both as adjuncts to the litigation process-either through a court referral or court-based program, or by an agreement between the parties-and outside litigation via private agreement. These proceedings are

78. The proposed Rule is numbered Rule 4.5 (contemplating an addition to the Model Rules section on "Transactions with Persons Other Than Clients," in simple numerical order). Ideally, "The Lawyer as Third Party Neutral" would be a new Rule 4, renumerating current rules.

Where possible, we use language, definitions, standards and formulations consistent with the current Model Rules. We also take note, where pertinent, of the ongoing work of the Ethics 2000 Commission of the American Bar Association, which is proposing revisions to the Model Rules of Professional Conduct, and the forthcoming Restatement of the Law Governing Lawyers, ratified by the American Law Institute in May 1999.

79. See Menkel-Meadow, Ethics in Alternative Dispute Resolution, supra note 1, at 430 (indicating the different "foundational principles" in non-adversarial practice, such as joint gain over individual gain, "future orientation" rather than "past orientation," thus illustrating a need for a separate regulatory scheme). 
commonly known as "ADR" processes.80 Some state ethics codes, statutes or court rules now require or strongly suggest that lawyers have a duty to counsel their clients regarding ADR means. ${ }^{81}$

When lawyers serve as ADR neutrals they do not have partisan clients, as contemplated in much of the Model Rules, rather, they serve all of the parties. Lawyer neutrals do not represent parties, but they have a duty to be fair to all participants in the process and to fufill different obligations and responsibilities with respect to the parties and process. ${ }^{82}$ Nor do the rules that apply to judges, such as the Judicial Code of Conduct, adequately deal with many issues confronting lawyer neutrals. For example, lawyers who act as third party neutrals in one case may serve as representational counsel in other matters and, thus, confront special conflicts of interest, appearance of impropriety, and confidentiality issues as they switch roles. ${ }^{83}$ Unlike the judge or arbitrator who remains at arms length from the parties and who usually hears information usually only when both parties are present, mediators have different ethical issues to contend with as they hear private, proprietary facts from both sides, in caucuses and ex parte communications. ${ }^{84}$

While there continues to be some controversy about whether serving as a mediator or arbitrator is the practice of law or may be covered by the ancillary practice Rule $5.7,{ }^{85}$ it is clear that lawyers serv.

80. The term "ADR" is used here to connote "appropriate dispute resolution," suggesting a choice of methods to be used to fit the matter. In more common parlance, ADR is used to connote "alternative dispute resolution" processes, which are seen as alternatives to more conventional trial or litigation methods.

81. See, e.g., Marshall Breger, Should an Attorney be Required to Advise a Client on $A D R$ Options? (discussion paper prepared for the ABA Section of Dispute Resolution and distributed at ABA Annual Meeting (1998)) (including listing of relevant statutes, court rules and ethical provisions); COLORADO RULE OF PROFESSIONAL CONDUCT Rule 2.1; Georgia RULES OF CIVIL PROCEDURE EC 7.5 (1996).

82. While the third party neutral does not represent or advocate for any of the parties to an ADR proceeding, in some circumstances, the third party neutral may provide information or advice to the parties without establishing a representational relationship. See infra, notes 85 and 86 and accompanying text.

83. See Poly Software Int'l, Inc. v. Su, 880 F. Supp. 1487, 1494 (D. Utah 1995) (holding that if a mediator hears confidential information through the course of a mediation, he may not represent a party in the same matter or one of substantial relation unless all par. ties to the mediation proceedings consent after disclosure).

84. See Cho v. Superior Court, 45 Cal. Rptr. 2d 863, 863-64 (1995) (holding that a law firm must be disqualified from a proceeding after hiring "the retired judge who had presided over the action and had received ex parte confidences from the opposing party in the course of settlement proceedings"). The Judicial Code of Conduct may also need revision to address new judicial roles in ADR, such as referral to ADR processes, ex parte communications with parties and third party neutrals, as well as judicial roles in settlement conferences. See Carrie Menkel-Meadow, Ex Parte Talks with Neutrals: ADR Hazards, 12 Alternatives to HIGH COST LITIG. 109, 109 (1994); see also Carrie Menkel-Meadow, Ju. dicial Referral to ADR: Issues \& Problems Faced by Judges, 7 F.J.C. DIRECTIONS 8, 8 (1994).

85. In 1994, Professor Geoffrey Hazard opined that activities in ADR can be considered "ancillary" functions of the lawyer, under current Rule 5.7, making the Model Rules 
ing as third party neutrals need ethical guidance from the Model Rules with respect to their dual roles as partisan representatives and as neutrals. The drafters believe it is especially important to develop clear ethical rules when the lawyer, commonly conceived of as a partisan representative, takes on the different role of neutral problem solver, facilitator or decision maker.

Lawyers may be disciplined for any violation of the Model Rules or misconduct, regardless of whether they are formally found to be serving in lawyer-like roles. Accordingly, while other associations provide guidance within specific contexts, ${ }^{86}$ when lawyers serve as mediators or arbitrators, their ethical duties and discipline under the Model Rules of Professional Conduct may be implicated. For these reasons, this proposed Rule is submitted to provide guidance for lawyers who serve as third party neutrals and to advise judicial officers and state discipline counsel who enforce lawyer ethical or disciplinary standards. $^{87}$

\section{B. Scope of the Proposed Model Rule}

The proposed Model Rule is drafted to govern lawyers serving in the full array of ADR neutral roles: as arbitrators, mediators, evaluators, and in other hybrid processes. The Drafting Committee believes that a general rule governing lawyers, serving in all third party neutral roles is appropriate because the proposed Rule addresses core ethical duties that apply to virtually all neutral roles. Where different neutral roles give rise to different duties and obligations, the proposed Rule so provides in text or comment. ${ }^{88} \mathrm{~A}$ single rule is also

applicable to lawyers serving in ADR situations. See Geoffrey C. Hazard, Jr., When ADR is Ancillary to a Legal Practice, Law Firms Must Confront Conflicts Issues, 12 Alternatives To High COST LITIG. 147, 147 (1994). The Commission believes that subsequent analysis and case law support the need for the new rule proposed here. See Cho, 45 Cal. Rptr. at 863; see also Poly Software Int'l, Inc. v. Su, 880 F. Supp. 1487, 1490-91 (D. Utah 1995); Menkel-Meadow, Ethics in Alternative Dispute Resolution, supra note 1, at 407; MenkelMeadow, Silences of the Restatement, supra note 1, at 631.

For commentary on the debate over whether mediation constitutes the practice of law, see Carrie Menkel-Meadow, Is Mediation the Practice of Law, 14 Alternatives To High Cost LITIG. 57 (1996); Bruce Meyerson, Lawyers Who Medjate are Not Practicing Law, 14 ALternatives to high COST Litig. 74 (1996); Symposium, Is Mediation the Practice of Law, NIDR Forum, June 1997; Geetha Ravindra, When Mediation Becomes the Unauthorized Practice of Law, 15 Alternatives to High COST Litig. 94 (1997); Carrie MenkelMeadow, To the Editors: Is Mediation the Practice of Law? Redux, NIDR News, Nov.-Dec. 1997, Jan. 1998, at 2.

86. See, e.g., AAAABA, THE CODE OF Ethics FOR ARBITRATORS IN COMMERCIAL DISPUTES (1977).

87. Whether third party neutrals will be liable in malpractice or on other legal theories to parties to an ADR is a question of state law.

88. In facilitating dispute resolution and planning transactions, in a variety of ways, neutrals may have different obligations with respect to various issues and within various contexts. For example, where ex parte or caucus sessions are used, different issues sur- 
consistent with the generally trans-substantive approach of the Model Rules. As the Model Rules recognize increasing diversity of lawyer roles, separate rules for lawyers as mediators or arbitrators may be appropriate in the future. ${ }^{89}$

The proposed Rule applies only to lawyers serving as third party neutrals. ${ }^{90}$ Many other professionals now serve as arbitrators, mediators, conciliators, evaluators or ombuds, and other bodies have promulgated transdisciplinary ethical rules relating to those services. ${ }^{91}$ When a lawyer serves as a third party neutral in a capacity governed by multiple sets of ethical standards, the lawyer must note that the Model Rules of Professional Conduct govern his/her duties as a lawyer neutral, and will govern the discipline of a third party neutral who is a lawyer. ${ }^{92}$ The proposed Rule does not govern lawyers in their capacities as representatives or advocates within ADR proceedings. When a lawyer serves as an advocate, representative or counselor to a party in an ADR proceeding, he or she is governed by such other rules as are applicable to lawyer conduct, either before tribunals ${ }^{93}$ or in relation to all other third parties..$^{94}$

rounding confidentiality may arise. Further, multiple use of a single neutral by one party may raise conflict of interest questions, depending on the neutral's role, the parties' agreement and the relevant jurisdictional regulations. See infra proposed Rule 4.5.4.

89. See MODEL RULes Rules 1.13 (Organization as Client), 2.1 (Lawyer as Advisor), 3.8, (Special Responsibilities of Lawyer as Prosecutor).

90. Also, the proposed Rule mainly governs issues of individual, ethical responsibility rather than organizational duties. However, with respect to conflicts of interest, both individual and organizational responsibilities are stated in the "imputation and screening" rule. See infra proposed Rule 4.5.4(b).

91. See, e.g., ABA AAAASPIDR MODEL STANDARDS FOR MEDIATORS (1994); SPIDR, ETHICAL STANDARDS OF PROFESSIONAL RESPONSIBILITY FOR THE SOCIETY OF PROFESSIONALS IN DISPUTE RESOLUTION (1986); ACADEMY OF FAMILY MEDIATORS, MODEL STANDARDS OF PRACTICE FOR FAMILY AND DIVORCE MEDIATION (1984).

92. This Rule distinguishes the lawyer's role as a neutral from the lawyer who may serve as an "intermediary" under Model Rule 2.2 and who therefore, "represents" several clients in an "intermediation" of their relationship such as a partnership, joint venture, or in some cases, divorce proceedings. The American Bar Association's Ethics 2000 Commission is currently reviewing the Model Rules and developing proposals for revision. A current Ethics Commission proposal calls for the elimination of Model Rule 2.2.

93. See MODEL RULES Rule 3.3.

94. See MODEL RULES Rule 4.1. A joint initiative of the CPR-Georgetown Commission and the ABA Dispute Resolution Section Ethics Committee is proposing amendments to the text and comments of existing Model Rules to address these issues. Among the issues being addressed by the Joint Initiative is the meaning and scope of the term "tribunal" in the Model Rules. The term "tribunal" in the Model Rules has been interpreted to apply to adjudicative or trial-type hearings, thereby arguably excluding facilitative-type processes. The Joint Initiative drafters believe that the term should be clarified to include ADR proceedings which are not adjudicative but held pursuant to court rules and regulations, whether proceedings are held within the courthouse or not.

The Joint Initiative, the Ethics 2000 Commission, and other groups are also considering current proposals to redraft Model Rules 3.3 and 4.1 to include increased duties of candor to tribunals, to clients and other third parties (such as in the rectification of fraud). In addition, rules that apply to the lawyer's role as counselor, Rules 2.1-2.3, for example, and general rules of lawyer-client relations, such as confidentiality, Model Rule 1.6, might also 
The proposed Rule, where possible, uses the same language and definitions of other lawyer and judicial standards, including formulations from the Model Rules of Professional Conduct, the Judicial Code of Conduct, the Code of Ethics for Arbitrators in Commercial Disputes, ${ }^{95}$ and the forthcoming Restatement of the Law Governing Lawyers. ${ }^{96}$ As the preamble to the Model Rules states, these rules are not to be used as liability standards for malpractice or other purposes. On the other hand, the forthcoming Restatement of the Law Governing Lawyers recognizes that ethical rules and standards are often used for civil liability, as well as for discipline, and this proposed Rule has been drafted accordingly.

\section{Definitions}

This Rule is intended to be applied to the duties and responsibilities of lawyers who act as third party neutrals in the following processes:

\section{Adjudicative}

Arbitration - A procedure in which each party presents its position and evidence before a single, neutral third party or a panel, who is empowered to render a resolution of the matter between the parties. Arbitrators may be chosen jointly by all parties, by contractual arrangements, under court or other rules, and, in some cases, may be chosen specifically by each side. Arbitrators chosen separately by each party to a dispute may be considered "partisan" arbitrators or "neutral" arbitrators, depending on the rules governing the arbitration. If the parties agree in advance or applicable law provides, the award is binding and enforceable in the same manner as any contractual obligation or under applicable statute (such as the Federal

need to be supplemented or amended to address different ethical responsibilities in different settings. See, e.g., Ethics 2000 Commission Rules 1.6, 3.3. Some have also suggested that the candor and good faith participation duties be heightened in some forms of ADR proceedings. See, e.g., Kimberlee K. Kovach, Lawyer Ethics in Mediation: Time for a Requirement of Good Faith, DISP. RESOL. MAG., Winter 1997, at 9 ("The rules and guidelines appropriate for an adversarial, third party determined outcome, are, at best, inapplicable to a participatory, interest-based mutual problem-solving process.").

95. AAA/ABA CODE OF ETHICS FOR ARBITRATORS IN COMMERCIAL DISPUTES (1997); These rules are currently being revised by the Ad Hoc Committee on the Code of Ethics for Arbitrators in Commercial Disputes Convened by the Arbitration Committee, Section on Dispute Resolution, American Bar Association.

96. The Restatement of the Law Governing Lawyers was ratified by the American Law Institute in May 1999. For commentary on the Restatements failure to address lawyering issues raised by ADR practice, see Carrie Menkel-Meadow, The Silences of the Restatement, supra note 1; Geoffrey C. Hazard, Jr., Non-Silences of Professor Hazard on "The Silences of the Restatement": A Response to Professor Menkel-Meadow, 10 GEO. J. OF LEGAL ETHICS 671 (1997). 
Arbitration Act or state equivalents). Agreements by the parties or applicable law may provide rules for whether the award must be in writing and what recourse the parties may have when the arbitration is not binding.

\section{Evaluative}

Neutral Evaluation - A procedure in which a third party neutral provides an assessment of the positions of the parties. In a neutral evaluation process, lawyers and/or parties present summaries of the facts, evidence, and legal principles applicable to their cases to a single neutral or a panel of neutral evaluators who then provide(s) an assessment of the strengths, weaknesses, and potential value of the case to all sides. By agreement of the parties or by applicable law, such evaluations are usually non-binding and offered to facilitate settlement. By agreement of the parties or by applicable law or practice, if the matter does not reach a settlement, the neutral evaluator may also provide other services such as case-planning guidance, discovery scheduling, or other settlement assistance. By agreement of the parties or applicable law, the neutral evaluator(s) may issue factfinding, discovery, and other reports or recommendations.

Mediation - A procedure in which a third party neutral facilitates communications and negotiations among the parties to effect resolution of the matter by agreement of the parties. In some forms of mediation the third party neutral may engage in evaluative tasks, such as providing legal information, helping parties and their counsel assess likely outcomes, and inquiring into the legal and factual strengths and weaknesses of the problems presented. By agreement of the parties or applicable law, mediators may sometimes be called on to act as evaluators or special discovery masters, or to perform other third party neutral roles.

\section{Facilitative}

Mediation - A procedure in which a third party neutral facilitates communication and negotiations among the parties to seek resolution of issues between the parties. Mediation is non-binding and does not, unless otherwise agreed to by the parties, authorize the third party neutral to evaluate (see above), decide or otherwise offer a judgment on the issues between the parties. If the mediation concludes in an agreement, that agreement, if it meets otherwise applicable law concerning the enforceability of contracts, is enforceable as a contractual agreement. Where authorized by applicable law, mediation agree- 
ments achieved during pending litigation may be entered as court judgments.

\section{Hybrid Processes}

Minitrial - A procedure in which parties and their counsel present their matter, which may include evidence, legal arguments, documents and other summaries of their case, before a neutral third party and representatives of all parties, for the purpose of defining issues, pursuing settlement negotiations, or otherwise sharing information. A neutral third party, usually at the parties' request, may issue an advisory opinion, which is non-binding unless the parties agree otherwise.

Med-arb - A procedure in which the parties initially seek mediation of their dispute before a third party neutral, but, if they reach impasse, may convert the proceeding into an arbitration in which the third party neutral renders an award. This process may also occur in reverse, in which, during a contested arbitration proceeding, the parties may agree to seek facilitation of a settlement (mediation) from the third party neutral. In some cases, these third party neutral functions may be divided between two separate individuals or panels of individuals.

Other - Parties, by agreement, or pursuant to court rules and regulations, may create and utilize other dispute resolution processes before third party neutral(s) in order to facilitate settlement, manage or plan discovery and other case issues, seek fact-finding or conciliation services, improve communication, simplify or settle parts of cases, arrange transactions or for other reasons. Such processes may be decisional (adjudicative), facilitative or a hybrid of the two, and they may be binding or non-binding as party agreements or court rules or statutes provide.

Lawyers who provide neutral services as described above shall be subject to the duties and obligations as specified below.

\section{RULE 4.5.1 DILIGENCE AND COMPETENCE}

(a) A lawyer serving as a third party neutral should act diligently, efficiently and promptly, subject to the standard of care owed the parties as required by applicable law or contract.

(b) A lawyer serving as a third party neutral should decline to serve in those matters in which the lawyer is not competent to serve. 
Comment

Diligence

[1] Like its equivalent in representational work (see Model Rule 1.3, discussing diligence in the lawyer-client relationship), this Rule requires the ADR neutral to act diligently, efficiently and promptly, subject to the duty of care owed the parties by applicable law or contract. Other rules or specifications of timeliness and standards of care may be specified in agreements of the parties, rules provided by relevant organizations, or by applicable case law dealing with mediator or arbitrator civil liability. The standard of care to be applied to the work of mediators and arbitrators is currently evolving in practice and case law.

[2] The lawyer neutral should commit the time necessary to promote prompt resolution of the dispute and should not let other matters interfere with the timely and efficient completion of the matter. If a lawyer neutral cannot meet the parties' expectations for prompt, diligent, and efficient resolution of the dispute, the lawyer neutral should decline to serve.

[3] While settlement or resolution is the goal of most ADR processes, the primary responsibility for the resolution of the dispute and the shaping of a settlement in mediation and evaluation rests with the parties. Accordingly, when serving in a facilitative or evaluative process (see definitions), the lawyer neutral should not coerce or im. properly influence a party to make a decision, to continue participating in the process, or to reach settlement or agreement. ${ }^{97}$

[4] When serving in an adjudicative or evaluative capacity, the lawyer neutral should decide all matters justly, exercising independent judgment, without permitting outside pressure to affect the decision. The lawyer neutral serving in adjudicative or evaluative roles should be guided by judicial standards of diligence and competence..$^{98}$

\section{Competence}

[5] A lawyer should decline appointment as a neutral when such appointment is beyond the lawyer's competence. A lawyer neutral

97. See Florida Rules for Certified and Court-Appointed Mediators Rule 10.031 (1998).

98. See MOdel CODE Of Judicial CONDUCT, Canon 3B; AAA/ABA CODE OF ETHICS FOR ARBITRATORS IN COMMERCIAL DISPUTES (1977). 
should serve "only in cases where the neutral has sufficient knowledge [and skill] regarding the process and subject matter to be effective." 99

[6] In determining whether a lawyer neutral has the requisite knowledge and skill to serve as neutral in a particular matter and process, relevant factors may include: the parties' reasonable expectations regarding the ADR process and the neutral's role, the procedural and substantive complexity of the matter and process, the lawyer neutral's general ADR experience and training, legal experience, subject matter expertise, the preparation the lawyer neutral is able to give to the matter, and the feasibility of employing experts or coneutrals with required substantive or process expertise. In many instances, a lawyer neutral may accept a neutral assignment where the requisite level of competence can be achieved by reasonable preparation.

\section{RULE 4.5.2 CONFIDENTIALITY}

(a) A lawyer serving as a third party neutral shall maintain the confidentiality of all information acquired in the course of serving as a third party neutral, unless the third party neutral is required or permitted by law or agreement of all the parties to disclose or use any otherwise confidential information.

(1) A third party neutral should discuss confidentiality rules and requirements with the parties at the beginning of any proceeding and obtain party consent with respect to any ex parte communication or practice.

(2) As between the parties, the third party neutral shall maintain confidentiality for all information disclosed to the third party neutral in confidence by a party, unless the party agrees or specifies otherwise.

(3) A lawyer who has served as a third party neutral shall not thereafter use information acquired in the ADR proceeding to the disadvantage of any party to the ADR proceeding, except when the information has become publicly known or the parties have agreed otherwise or except when necessary under section (b), below, or to defend the neutral from a charge of misconduct.

(b) A third party neutral may use or disclose confidential information obtained during a proceeding when and to the extent the third party believes necessary to prevent:

(1) death or serious bodily injury from occurring; or

99. SPIDR, ETHICAL STANDARDS OF PROFESSIONAL RESPONSIBILITY FOR THE SOCIETY of PROFESSIONALS IN DISPUTE RESOLUTION (1986). 
(2) substantial financial loss from occurring in the matter at hand as the result of a crime or fraud that a party has committed or intends to commit.

(c) Before using or disclosing information pursuant to section (b), if not otherwise required to be disclosed, the third party neutral must, if feasible, make a good faith effort to persuade the party's counsel or the party, if the party is unrepresented, either not to act or to warn those who might be harmed by the party's action.

\section{Comment}

[1] ADR confidentiality is distinctly different from lawyer-client confidentiality, which is defeated when adverse parties reveal information to each other or in the presence of a third party. The extent of ADR confidentiality protections can be determined by contract, court rules, statutes, or other professional norms or rules. This Rule addresses the confidentiality responsibilities of the lawyer neutral and delineates the neutral's duties to the parties, the process, and the public. ${ }^{100}$

[2] Principles of confidentiality are given effect in the laws of evidence (which govern evidentiary uses, restrictions and privileges) and in ethics rules (which establish professional ethical obligations). Privileges apply in judicial and other proceedings in which the lawyer neutral may be called as a witness or otherwise required to produce evidence regarding an ADR process. The rule of confidentiality in professional ethics applies in situations other than those where evidence is sought from the lawyer neutral through compulsion of law. This Rule is intended to provide the ADR neutral and parties with confidentiality protections for ADR processes where privacy of the process and unguarded, candid communications are central to their use and effectiveness.

[3] Since there is no attorney-client relationship between parties and lawyer neutrals, and because most disclosures of information in most forms of $\mathrm{ADR}$ occur in the presence of the other party, the confidentiality protection guaranteed to clients by their representational lawyers by Model Rule 1.6 (as well as the evidentiary privilege of attorney-client) does not apply in most $\mathrm{ADR}$ settings.

[4] The general rule that lawyers may divulge confidences to facilitate law practice within the firm is not applicable in ADR confi. dentiality, especially mediation. "Since the essence of mediation is

100. See Poly Software Int'l, Inc. v. Su, 880 F. Supp. 1487, 1494 (D. Utah 1995); Cho v. Superior Court, 45 Cal. Rptr. 2d 863 (1995); Symposium, Confidentiality in Mediation, DISP. RESOL. MAG., Winter 1999. 
the preservation of confidential communications, most lawyermediators are scrupulous not to disclose such confidential information to anyone, even attorneys in their own firm. Mediators may discuss fact patterns or mediation issues with other mediators within the firm or the community of mediators. As a matter of routine, most mediators will screen such comments to ensure that they never reveal names or confidential information." 101

[5] .This Rule imposes an ethical duty of confidentiality on the ADR neutral to protect the ADR process and the parties. The rule's confidentiality standards can be altered by agreement of all parties or applicable law.

Many jurisdictions and courts provide confidentiality protections to parties and ADR neutrals as a matter of law. While some statutes are narrowly evidentiary in nature and govern only the use of information in a court proceeding, other mediation confidentiality provisions include both evidentiary restrictions and broader prohibitions against disclosure. ${ }^{102}$ Additionally, confidentiality is often provided by contract among parties and neutrals in private forums. ${ }^{103}$

[6] Since ADR confidentiality can be governed by different and sometimes conflicting sources of law and ethical duties, it is important that the parties and the neutral understand the extent and uncertainties of the ADR confidentiality protections. Accordingly, section (1) requires the third party neutral to discuss the applicable confidentiality rules with the parties and counsel at the beginning of the process.

Statutory or common law privileges, evidence codes, protective orders issued by courts under discovery or other statutes, as well as party contracts and court rules all can affect the scope of confidentiality for the parties, the third party neutral and others outside of the particular matter. ${ }^{104}$ Some states, for example, require mediators to disclose certain information, like the occurrence of child abuse or domestic violence. ${ }^{105}$ Additionally this Rule, like the ABA's Ethics

101. James E. McGuire, Conflicts in Subsequent Representation, DISP. RESOL. MAG., Spring 1996, at 4.

102. See Nancy Rogers \& Craig McEwen, Mediation: Law, Policy and Practice (2d ed. 1994) (noting that state legislatures have enacted over 200 mediation statutes); ElizabeTh Plapinger \& DONNa STIENSTRA, ADR AND SETTLEMENT IN THE FEDERAL DISTRICT COURTS: A SOURCEBOOK FOR JUDGES AND LAWYERS (1996) (noting that federal district courts provide for confidentiality of ADR processes by local rule or court orders).

103. See, e.g., MODEl ADR PROCEDURES AND PRACTICES: MEDIATION PROCEDURE para. 9 (CPR Institute for Dispute Resolution 1998) (containing confidentiality provision); MODEl ADR PROCEDURE AND PRACTICES: CONFIDENTIALITY (CPR Institute for Dispute Resolution 1998).

104. See ROGERS \& MCEWEN, supra note 102.

105. See, e.g., CAL. PENAL CODE § 11164 (1993). 
2000 Commission's proposed revision of Model Rule 1.6 and the forthcoming Restatement of the Law Governing Lawyers, section 117, permits disclosure of information to prevent imminent bodily harm or substantial financial loss. See Comment [10] below.

[7] In addition to advising the parties about the scope of confidentiality protections under law and applicable agreement, section (1) also requires the neutral to discuss and obtain party consent regarding the nature of ex parte communications, if any, contemplated by the process. In some mediation processes, for example, parties meet separately with the mediator and share information confidentially. In arbitration processes, ex-parte communications with partisan arbitrators may be permitted under certain rules and prohibited under others. ${ }^{106}$

[8] Given the extensive use in mediation of separate, ex parte meetings or caucuses with the mediator, parties and their lawyers may reveal information in caucus that is not to be disclosed to the other party without permission. Section (2) establishes that the neutral shall maintain the confidentiality of all information disclosed to the third party in confidence, unless the party agrees or specifies otherwise. In effect, all information revealed in confidence in exparte sessions or through other confidential means, is to be considered confidential, absent a specific statement or agreement by the party otherwise.

[9] Section (3) prohibits the neutral from using any information acquired in the ADR proceeding to the disadvantage of any party, subject to the exceptions stated in the rule. This formulation tracks the current Model Rule 1.9(c)(1) for conflicts of interest for representational attorneys and former clients. Particularly in mediation or other ADR fora where ex parte sessions are used, the third party neutral may hear information or settlement facts that may not be le. gally relevant but are highly sensitive or proprietary. Under this rule, the lawyer neutral is prohibited from using this information in subsequent neutral or representational work to the disadvantage of the former ADR party.

[10] Like the ABA's Ethics 2000 Commission's proposed version of Model Rule 1.6 and the forthcoming Restatement of the Law Gov-

106. See, e.g., AAAABA CODE OF ETHICS FOR ARBITRATORS IN COMMERCIAL DISPUTES Canon VIL.C(2) (1977) (permitting ex-parte communications between the non-neutral arbitrator and the party who appointed them); CPR RULES FOR NON-ADMINISTERED ARBITRATION Rule 9.3 (1998) (prohibiting ex-parte communications with neutral or partyappointed arbitrators). 
erning Lawyers, section 117, this rule permits disclosure by the neutral third party of information to prevent death or serious bodily harm to anyone on the basis of any information learned, and disclosure to prevent substantial financial loss from occurring in the matter at hand, as a result of a crime or fraud one of the parties has committed or intends to commit. Several states, notably New Jersey and Florida, require (not just permit) lawyers to reveal information to prevent death or serious bodily harm, as well as to avoid some criminal acts or fraud on the tribunal, even when learned in an otherwise confidentially-protected situation. ${ }^{107}$

In many jurisdictions, third party neutrals are already under an obligation to reveal such information under separate statutes or case law. ${ }^{108}$

\section{RULE 4.5.3 IMPARTIALITY}

(a) A lawyer who serves as a third party neutral should be impartial with respect to the issues and the parties in the matter.

(1) A lawyer who serves as a third party neutral should conduct all proceedings in an impartial, unbiased and evenhanded manner, treating all parties with fairness and respect. If at any time the lawyer is unable to conduct the process in an impartial manner, the lawyer shall withdraw, unless prohibited from doing so by applicable law.

(2) A lawyer serving in a third party neutral capacity should not allow other matters to interfere with the lawyer's impartiality.

(3) When serving in an adjudicative capacity, the lawyer shall decide all matters fairly, with impartiality, exercising independent judgment and without any improper outside influence.

(b) A lawyer who serves as a third party neutral should:

(1) Disclose to the parties all circumstances, reasonably known to the lawyer, why the lawyer might not be perceived to be impartial. These circumstances include (I) any financial or personal interest in the outcome; (II) any existing or past financial, business, professional, family or social relationship with any of the parties, including, but not limited to, any prior representation of any of the parties, their counsel and witnesses, or service as an ADR neutral for any of the parties; (III) any other source of bias or prejudice concerning a person or institution which is likely to affect impartiality or

107. See, e.g., N.J. RULES OF PROFESSIONAL CONDUCT Rule 1.6 (1998).

108. See, e.g., CAL. PENAL CODE $\S 11164$ (1992) (requiring child abuse to be reported); IDAHO RULES OF EVD. 507(4) (1998) (stating that child abuse discovered during mediation is not a protected confidence); Tarasoff $v$. Regents of the Univ. of Cal., 17 Cal. 3d 425, 449. 50 (1976) (placing an affirmative duty on psychologist to inform patient's intended victim of danger). 
which might reasonably create an appearance of partiality or bias; and (IV) any other disclosures required of the lawyer by law or contract.

(2) Conduct a reasonable inquiry and effort to determine if any interests or biases described in section (b)(1) exist, and maintain a continuing obligation to disclose any such interests or potential biases which may arise during the proceedings.

(3) Decline to participate as a third party neutral unless all parties choose to retain the neutral, following all such disclosures, unless contract or applicable law requires participation. If, however, the lawyer believes that the matters disclosed would inhibit the lawyer's impartiality, the lawyer should decline to proceed.

(c) All disclosures under section (b) extend to those of the lawyer, members of his or her family, his or her current employer, partners or business associates.

(d) After accepting appointment and while serving as a neutral, a lawyer shall not enter into any financial, business, professional, family or social relationship or acquire any financial or personal interest which is likely to affect impartiality or which might reasonably create the appearance of partiality or bias, without disclosure and consent of all parties.

\section{Comment}

Impartiality

[1] Impartiality means freedom from favoritism or bias either by word or action, and a commitment to serve the process and all parties equally. Section (a) codifies established concepts of neutrality and neutral conduct.

\section{Disclosure}

[2] Understanding that absolute neutrality is unobtainable even under the best circumstances, this rule establishes a broad and continuing standard of disclosure by lawyer neutrals with the possibility of waiver by the parties. The rule describes the circumstances which should be disclosed in determining whether the neutral third party is without impermissible partiality and bias to serve in the particular matter. This form of disclosure is accepted practice in ADR proceedings, including both arbitration and mediation.

A lawyer, as prospective neutral, should err on the side of disclosure because it is better that the relationship or other matter be disclosed at the outset when the parties are free to reject the prospective 
neutral or to accept the person with knowledge of the relationship..$^{109}$ While there is often disagreement over what may reasonably constitute a potential conflict, the growing acceptance of the principle of disclosure acts as some reassurance that potentially disadvantaged parties will be given an opportunity to object or at least investigate further. ${ }^{110}$ Conversely, it allows all parties to select a neutral after full disclosure, where the parties knowingly decide to go forward.

[3] Where possible, best practices suggest that the disclosures should be in writing, as should any subsequent waivers or consents. While the ABA's Ethics 2000 Commission revision of Model Rule 1.7 currently requires written disclosures of all representational conflicts and waivers, this section advises, but does not require, the preparation of written disclosures and consents. ${ }^{111}$

[4] What constitutes reasonable inquiry and effort by the lawyer neutral to uncover interests or relationships requiring disclosure depends on the circumstances. Typically, in matters where the parties are represented, this will involve the prospective lawyer neutral obtaining from the parties a complete identification of the parties, their representatives, insurers, lawyers, witnesses and attendees at the ADR proceeding and submitting the list to the prospective neutral's conflicts system. ${ }^{112}$ We note that there may be a tension under the law between the duty to disclose prior matters, clients, financial holdings, etc., and the confidentiality required to be maintained with respect to ongoing or concluded representations and ADR proceedings.

The rule defines the scope of required disclosure to include immediate family members, and business partners and associates as defined in Model Rule 1.8 (i). ${ }^{13}$ It also follows Rule 1.10 and The Restatement of the Law Governing Lawyers, section 203, for definitions of business associations and law firm associations. ${ }^{14}$ The rule does not follow the Judicial Code of Conduct Canon $3(\mathrm{E})(1)(\mathrm{d})$.

109. See Commonwealth Coatings Corp. v. Continental Co., 393 U.S. 145, 151-52 (1968) (White, J., concurring).

110. See Christopher Honeyman, Patterns of Bias in Mediation, 1985 MO. J. OF DiSP. RESOL. 141 (1985).

111. Cf. Calif. Arbitration Statute, CAL. CIV. Proc. CoDE $\$$ 1281.9(a) (Deering 1998) (recording the California Arbitration Statute and requiring all conflict disclosures in writing).

112. See Al-Harbi v. Citibank, 85 F.3d 680, 681-83 (D.C. Cir. 1996).

113. The ABA's Ethics 2000 Commission is currently considering changes to this Model Rule of Professional Conduct.

114. The proposed Restatement of the Law Governing Lawyers was ratified by the American Law Institute in May 1999. 
[5] Where a lawyer neutral volunteers to act as a neutral at the request of a court, public agency or other group for a de minimis period and pro bono publico, section (b)(2) recognizes that there may not be opportunity for full inquiry, disclosure or disqualification challenge. In such circumstances, a third party neutral may have to proceed with the minimal inquiry and disclosure that may be reasonable under the circumstances. If the lawyer, from memory, recognizes an interest or relationship relevant to the case, the lawyer should identify that interest or relationship. Otherwise, the lawyer should disclose the general nature of the lawyer neutral's practice and affiliations with law firms or other associations, or other known disqualifying circumstances. ${ }^{115}$

[6] In general, parties may elect to retain a lawyer as neutral after the latter's disclosure of reasons why the lawyer reasonably might be perceived not to be neutral. However, section (b)(3) imposes on the lawyer neutral the obligation to decline to serve if the lawyerneutral believes that the matters disclosed, or other circumstances, would inhibit the lawyer's impartiality or otherwise impugn the integrity of the process. In such instances, the lawyer neutral should decline to serve even if the parties consent to the lawyer's retention as a neutral.

[7] Section (d) tracks language from the Code of Ethics for Arbitrators in Commercial Disputes, currently under revision, and is intended to prevent partiality from developing through the acquisition of future business during the pendency of an ADR proceeding. The parties may consent to waive this provision. The consent provision may prevent difficulties for third party neutrals engaged to mediate or arbitrate a number of disputes with the same party, either through contractual appointment pre-dispute or through multiple, simultaneous appointments or appointments during the pendency of a particular case.

\section{RULE 4.5.4 CONFLICTS OF INTEREST}

(a) Disqualification of Individual Third Party Neutrals

(1) A lawyer who is serving as a third party neutral shall not, during the course of an ADR proceeding, seek to establish any financial, business, representational, neutral or personal relationship with or acquire an interest in, any party, entity or counsel who is involved in the matter in which the lawyer is participating as a neutral, unless all parties consent after full disclosure. 
(2) A lawyer who has served as a third party neutral shall not subsequently represent any party to the ADR proceeding (in which the third party neutral served as neutral) in the same or a substantially related matter, unless all parties consent after full disclosure.

(3) A lawyer who has served as a third party neutral shall not subsequently represent a party adverse to a former ADR party where the lawyer neutral has acquired information protected by confidentiality under this Rule, without the consent of the former ADR party.

(4) Where the circumstances might reasonably create the appearance that the neutral had been influenced in the ADR process by the anticipation or expectation of a subsequent relationship or interest, a lawyer who has served as a third party neutral shall not subsequently acquire an interest in, or represent, a party to the ADR proceeding in a substantially unrelated matter for a period of one year or other reasonable period of time under the circumstances, unless all parties consent after full disclosure.

(b) Imputation of Conflicts to Affiliated Lawyers and Removing Imputation

(1) If a lawyer is disqualified by section (a), no lawyer who is affiliated with that lawyer may knowingly undertake or continue representation in any substantially related or unrelated matter un. less the personally disqualified lawyer is adequately screened from any participation in the matter, is apportioned no fee from the matter and timely and adequate notice of the screening has been provided to all affected parties and tribunals, provided that no material confidential information about any of the parties to the ADR proceeding has been communicated by the personally disqualified lawyer to the affiliated lawyer or that lawyer's firm.

(c) A lawyer selected as a partisan arbitrator of a party in a multi-member arbitration panel is not prohibited from subsequently representing that party, nor are any affiliated lawyers.

(d) If a lawyer serves as a neutral at the request of a court, public agency or other group for a de minimis period and pro bono publico, the firm with which the lawyer is associated is not subject to imputation under section (b).

Comment

Conflicts

[1] ADR conflicts policy, like all conflicts regulation, has two main objectives: to protect the parties from actual harm suffered by conflicts of interest, and to protect the process, the public, and the parties from the "appearance" of improper influences. In the ADR context, it is essential that conflicts rules protect against both actual harm and the appearance of self-interest. 
Modern law practice is increasingly characterized by lawyer mobility, both externally where lawyers move among law firms and organizations, and internally where lawyers on a case-by-case basis move from representative to neutral roles within their law firms and through association with other private or public organizations (such as court or bar volunteer ADR programs). This Rule strives to protect against both actual harm from lawyer role changes, ${ }^{116}$ and to protect the $\mathrm{ADR}$ processes, the lawyer neutrals, the parties and the public against the corrosive but less tangible "appearance of impropriety" or "public" harms which threaten the integrity of these processes, the neutrality of the lawyer neutrals, and the public's confidence in these dispute resolution procedures. ${ }^{117}$

[2] Section (a)(1) governs conflicts that may arise during the pendency of an $A D R$ process and is intended to be a bar against using the ADR process to obtain additional employment or other benefit. Conflicts arising under this section can be consented to by all parties after full disclosure.

[3] Section (a)(2) prohibits future representational roles by lawyer neutrals in the same or substantially related matters, absent disclosure and consent by all parties. This section codifies the rule established in Poly Software: "Where a mediator has received confidential information in the course of a mediation, that mediator should not thereafter represent anyone in connection with the same or a substantially factually related matter unless all parties to the mediation consent after disclosure." Poly Software, 880 F. Supp. at 1495. We believe that the logic behind Poly Software's prohibition of future representational relationships in the same or substantially related cases also applies to adjudicative processes such as arbitration. Accordingly, under this Rule, a neutral arbitrator is subject to the same restrictions as a mediator, although a partisan arbitrator is excepted from these restrictions by section (c).

116. See Poly Software Int'l, Inc. v. Su, 880 F. Supp. 1487, 1494 (D. Utah 1995). The court disqualified a lawyer-mediator from representing a litigant in a subsequent matter related to an earlier case in which the mediator had received confidences from the parties. See id.; see also Cho v. Superior Court, 45 Cal. Rptr. 2d 863, 863-64 (1995). The court disqualified the law firm as counsel after the firm hired the retired judge who had previously presided over the action and had participated in settlement conferences with the parties. See id. The court also rejected the use of Rule 1.12 for screening of a former judge or arbitrator.

117. See Cho, 45 Cal. Rptr. at 863 . Although the firm had established a screening process to shield the former judge from the case, and the judge stated that he had no recall of the settlement conferences, the court stated that "no one could have confidence in the integrity of a legal process" where the former judge who received ex-parte revelations from one of the parties joins the opposing counsel's law firm. 
[4] Conflicts may exist when lawyer neutrals, who have facilitated disputes and learned confidential and proprietary information about the disputing parties, are asked to represent a party adverse to a former ADR party. When trying to facilitate solutions, third party neutrals may learn significant "settlement facts"-proprietary information about entities or individuals learned within the neutral setting that may not be legally relevant but that affect the possibility of settlement. ${ }^{118}$ In this situation, the conflicts issue is whether an ADR neutral who learned facts (e.g., about financial solvency, human relations, product development, acquisitions or entity future plans) during the ADR would or could use those facts against the former ADR party in the subsequent representation. Section (a)(3) addresses this situation by prohibiting a lawyer neutral from representing a party adverse to a former ADR party where the lawyer neutral has acquired settlement facts or other information protected by this rule's confidentiality provision, Rule 4.5.2, absent consent by the former ADR party.

[5] Section (a)(4) addresses potential future representational or other relationships between the lawyer neutral and a party to the prior ADR in unrelated cases. The bar often refers to these relationships as "downstream conflicts." This section is designed to protect against the appearance or the actuality that. an expectation of a beneficial future relationship or interest has influenced the neutral's conduct in the preceding ADR process. The language in this section is derived from Canon I.D. of the Code of Ethics for Arbitrators in Commercial Disputes (AAA-ABA, 1997) (currently under revision). ${ }^{119}$

\section{Imputation and Screening}

[6] This rule follows the trend of the Restatement of the Law Governing Lawyers to provide for screening of lawyer neutrals disqualified under section (a) in unrelated or substantially related matters. This formulation continues to impute disqualification to the whole firm for the same matter. ${ }^{120}$ This rule is premised, in part, on

118. See Menkel-Meadow, The Silences of the Restatement, supra note 1.

119. This Rule provides for a presumptive one-year period of disqualification, but also provides flexibility to shorten or lengthen the disqualification period, as circumstances require. Although the Model Rules of Professional Conduct prefer general and not time-based rules, the Drafting Committee and consulting member Professor Geoffrey Hazard believe that a presumptive one-year safe-harbor period is preferable to a general rule of reasonableness, given the substantial need among lawyers and law firms for a clearly defined rule. Understanding that the time-based rule will not be appropriate in all circumstances, a rule of reasonableness is also included.

120. See Cho v. Superior Court of Los Angeles, 45 Cal. Rptr. 2d 863 (1995) (screening not sufficient to defeat law firm's disqualification when the judge who heard the action and 
the different confidentiality obligations of third party neutrals and lawyer representatives. Unlike lawyers representing clients, lawyer neutrals generally should not share information with other lawyers in their firm, and thus are particularly well suited for screening. See Comment [4] to Rule 4.5.2, Confidentiality.

An alternative formulation, which the Drafting Committee rejected, would apply the current non-screen, imputation formulation of Model Rule 1.10. This rule would read: "Unless all affected parties consent after disclosure, in any matter where a lawyer would be disqualified under section (a), the restrictions imposed therein also restrict all other lawyers who are affiliated with that lawyer under Rule 1.10." We believe that a no-screen imputation rule is contrary to the trend in the law, as noted above, and would inappropriately limit the growth of mixed neutral and representational roles for lawyers, with its attendant benefits to both the practice and the public.

[7] Screening in the ADR context involves the same actions as screening in other contexts. ${ }^{121}$ In addition, under the proposed Rule, notice of the screening must be provided to all affected parties and tribunals.

[8] Section (c) excepts partisan, party-appointed arbitrators from the restrictions on future representational work under section (a), and from imputation and screening under section (b). We note, how. ever, the lack of consensus regarding the role and practices of partisan arbitrators, and suggest that if "partisan" arbitrators become more like neutral arbitrators, section (c) will have to be amended.

[9] Section (d) excepts lawyer neutrals and their affiliated lawyers from the imputation and screening rule when the lawyer neutral volunteers his or her services at the request of a court, other public agency, or institution and serves for a de minimis period.

presided over confidential, ex parte settlement conferences joined the opposing party's law firm).

121. See, e.g., MODEL RULES Rule 1.11(a)(1) (permitting the law firm of a former government lawyer to undertake or continue representation in a matter in which the former government lawyer participated personally and substantially if the lawyer is screened from further participation in it, including receipt of fees from it). Annotated Model Rule 1.11 states: "An effective screen commonly includes the following factors: (1) the disqualified lawyer does not participate in the matter, (2) the disqualified lawyer does not discuss the matter with any member of the firm, (3) the disqualified lawyer represents through sworn testimony that he or she had not imparted any confidential information to the firm, (4) the disqualified lawyer does not have access to any files or documents relating to the matter; and (5) the disqualified lawyer does not share in any of the fees from the matter." See ABA ANNOTATED MOdel Rules OF PROFESSIONAL CONDUCT 186 (3d ed. 1996). 


\section{RULE 4.5.5 FEes}

(a) Before or within a reasonable time after being retained as a third party neutral, a lawyer should communicate to the parties, in writing, the basis or rate and allocation of the fee for service, unless the third party neutral is serving in a no-fee or pro bono capacity.

(b) A third party neutral who withdraws from a case should return any unearned fee to the parties.

(c) A third party neutral who charges a fee dependent on the settlement or other specific resolution of the matter should explain to the parties that such an arrangement gives the third party neutral a direct financial interest in settlement that may conflict with the parties' possible interest in terminating the proceedings without reaching settlement. The third party neutral should consider whether such a fee arrangement creates an appearance or actuality of partiality, inconsistent with the requirements of Rule 4.5.3.

\section{Comment}

[1] This rule requires a written communication specifying the basis, rate and allocation of fees to all parties, unless the third party neutral is serving in a no-fee or pro bono capacity.

[2] It has become relatively common to use contingent fee or bonus compensation schemes to provide an incentive to participate in ADR or to reward the achievement of an effective settlement. Section (3) of the rule does not prohibit contingent fees (which some jurisdictions or provider organizations do) but requires the third party neutral to explain what the effects of such a fee arrangement may be, including conflicts of interest. This rule imposes two obligations on the neutral. The lawyer neutral is required to assess the possible conflicts attendant to use of contingent fees and whether the appearance or actuality of partiality prohibits its use under Rule 4.5.3, Impartiality. If use of the compensation arrangements is not prohibited under that standard, the neutral is required to disclose the possible consequences of this fee arrangement to the parties. Contingent fees have not been totally prohibited by this rule because of their use in creating incentives for some parties to participate in mediation or other settlement activities.

\section{RULE 4.5.6 FAIRNESS AND INTEGRITY OF THE PROCESS}

(a) The lawyer serving as third party neutral should make reasonable efforts to determine that the ADR proceedings utilized are explained to the parties and their counsel, and that the parties knowingly consent to the process being used and the neutral selected 
(unless applicable law or contract requires use of a particular process or third party neutral).

(b) The third party neutral should not engage in any process or procedure not consented to by the parties (unless required by applicable law or contract).

(c) The third party neutral should use all reasonable efforts to conduct the process with fairness to all parties. The third party neutral should be especially diligent that parties who are not represented have adequate opportunities to be heard and involved in any $\mathrm{ADR}$ proceedings.

(d) The third party neutral should make reasonable efforts to prevent misconduct that would invalidate any settlement. The third party neutral should also make reasonable efforts to determine that the parties have reached agreement of their own volition and knowingly consent to any settlement.

\section{Comment}

[1] While ethical rules cannot guarantee the specific procedures or fairness of a process, this rule is intended to require third party neutrals to be attentive to the basic values and goals informing fair dispute resolution. These values include party autonomy; party choice of process (to the extent permitted by law or contract); party choice of and consent to the choice of the third party neutral (to the extent permitted by law or contract); and fairness of the conduct of the process itself. This Rule is concerned not only with specific harms to particular participating parties but with the appearance of the integrity of the process to the public and other possible users of these processes. ${ }^{122}$

122. The proposed Rule articulates a preferred rule of party choice and autonomy, about the type of process (including whether mediation is facilitative or evaluative), whether caucuses are to be used or not, and the selection of the neutral. This may not be possible in situations where processes are mandated, either by contract (adhesion or freely negotiated) or by court rules and requirements. The questions implicated in the fairness and integrity of the process are very controversial at the present time (including legal challenges to compulsory arbitration clauses in some contracts) and thus, we (or the appropriate ABA ethics body) might conclude that such a matter is too "substantive" or too unsettled for rule-making at this time.

As we write this, the case law is rapidly changing. The U.S. Supreme Court recently held that an arbitration clause in a collective bargaining agreement must clearly and unmistakably state that federal anti-discrimination claims are subject to arbitration. See Wright v. Universal Maritime Serv. Corp., 119 S. Ct. 391 (1998). Similarly, the Ninth Circuit has refused to enforce arbitration in several employment cases where the plaintiffs did not knowingly agree to arbitrate statutory discrimination claims. See Duffield v. Richardson Stephens \& Co., 144 F.3d 1182 (9th Cir. 1998); see also Renteria v. Prudential Ins. Co. of Am., 113 F.3d 1104 (9th Cir. 1997); Nelson v. Cyprus Bagdad Copper Corp., 119 F.3d 756 (9th Cir. 1997).

The California Supreme Court also raised serious questions about the fairness and enforceability of Kaiser's contractual mandatory medical malpractice arbitration. See Engalla v. Kaiser Permanente Med. Group, Inc., 64 Cal. Rptr. $2 d 843$ (1997). Engalla has lead to a 
[2] This section requires third party neutrals to make reasonable efforts to determine that the parties have reached an agreement of their own volition, one that is not coerced. While some have suggested that third party neutrals should bear some moral accountability or legal responsibility for the agreements they help facilitate, ${ }^{123}$ these Rules do not make the third party neutral the guarantor of a fair or just result.

[3] This section of the Rule is designed to prevent harm not only to parties engaged in dispute resolution processes, but to the appearances presented to the general public of how legal processes are conducted. Although this section of the Rule may suffer from the same complaints about vagueness as the former Canon 9 "appearance of impropriety" did under the old structure of the Model Code of Professional Responsibility, the drafters believe that where lawyers "switch" sides and roles, from partisan to neutral, it is important to provide for basic criteria of fairness to be monitored in the process for the acceptability and legitimacy of the process and the lawyers within it.

comprehensive assessment and restructuring of the Kaiser arbitration process by outside experts. See The Blue Ribion advisony PANEL ON KaISer Permanente ARBitration, The Kaiser Permanente ARBitration System: A REVIEW and Recommendations for IMPROVEMENT (January 5, 1998).

123. See Lawrence Susskind, Environmental Mediation and the Accountability Problem, 9 VT. L. REV. 1 (1981). The Kutak Commission rejected an earlier effort to prevent lawyers from facilitating negotiated agreements that would be held unconscionable as a matter of law. See MODEL RULES proposed Rule 4.3 (draft version 1980). 